for Anadromous Salmonids and Resident Fish in the Columbia River Basin

- Demonstration Period, 1992 - 1994

A Comprehensive Columbia Basin Cooperative Law Enforcement Program Comprised of Six Performance Grants and Inter-Agency Agreements

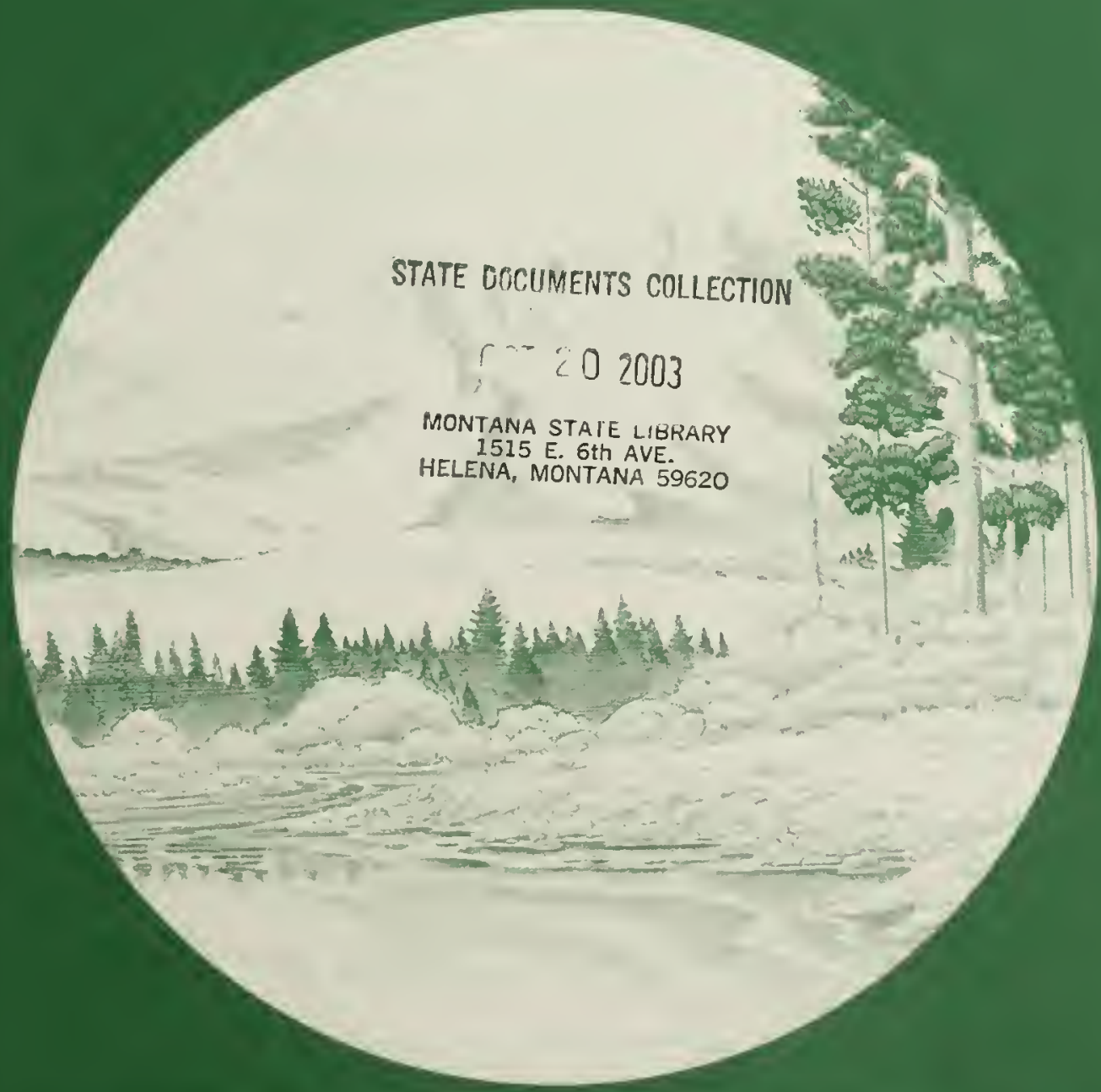

U.S. Department of Energy

Brnneville Power Administratinn Divisikn of Fish o Wildilife

\section{Columbia River Inter-Tribal Fish}

Commission

Oregon Department of State Police

Washingthn Department of Fish and Willilice

Idaho Nepartment of Fish

National Marine Fisheries Service

Montana Degpartment of Fish Wilflipic, and Parks 
This report was funded by the Bonneville Power Administration (BPA), U.S. Department of Energy, as part of BPA's program to protect, mitigate, and enhance fish and wildlife affected by the development and operation of hydroelectric facilities on the Columbia River and its tributaries. The views in this report are the author's and do not necessarily represent the views of BPA.

For additional copies of this report, write to:

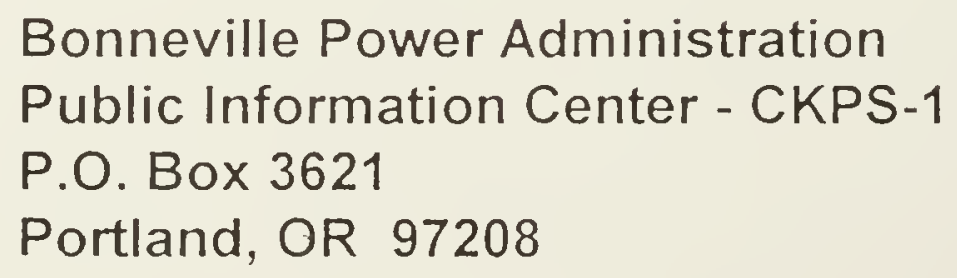

Please include title, author, and DOE/BP number from the back cover in the request. 


\title{
INCREASED LEVELS OF HARVEST AND HABITAT LAW ENFORCEMENT AND PUBLIC AWARENESS FOR ANADROMOUS SALMONIDS AND RESIDENT FISH IN THE COLUMBIA RIVER BASIN - DEMONSTRATION PERIOD, 1992-1994
}

\section{FINAL REPORT}

\section{A Comprehensive Columbia Basin Cooperative Law Enforcement Program Comprised of Six Performance Grants and Inter-Agency Agreements}

\author{
Prepared by: \\ Columbia River Inter-Tribal Fish Commission \\ Oregon Department of State Police \\ Washington Department of Fish and Wildlife \\ Idaho Department of Fish and Game \\ National Marine Fisheries Service \\ Montana Department of Fish, Wildlife and Parks
}

Prepared for:

Steven Vigg, Editor

U.S. Department of Energy

Bonneville Power Administration

Environment, Fish and Wildlife

P. O. Box 3621

Portland, OR 97208-3621

Contract Number DE-FG79-92BP28111 Project Number 92-024-01

Contract Number DE-FG79-92BP28112 Project Number 92-024-02

Contract Number DE-FG79-92BP28114 Project Number 92-024-03

Contract Number DE-FG79-92BP28116 Project Number 92-024-04

Contract Number DE-AI79-93BP10943 Project Number 92-024-05

Contract Number DE-FG79-95BP36597 Project Number 92-024-06

June 1995 


\section{DATE DUE}

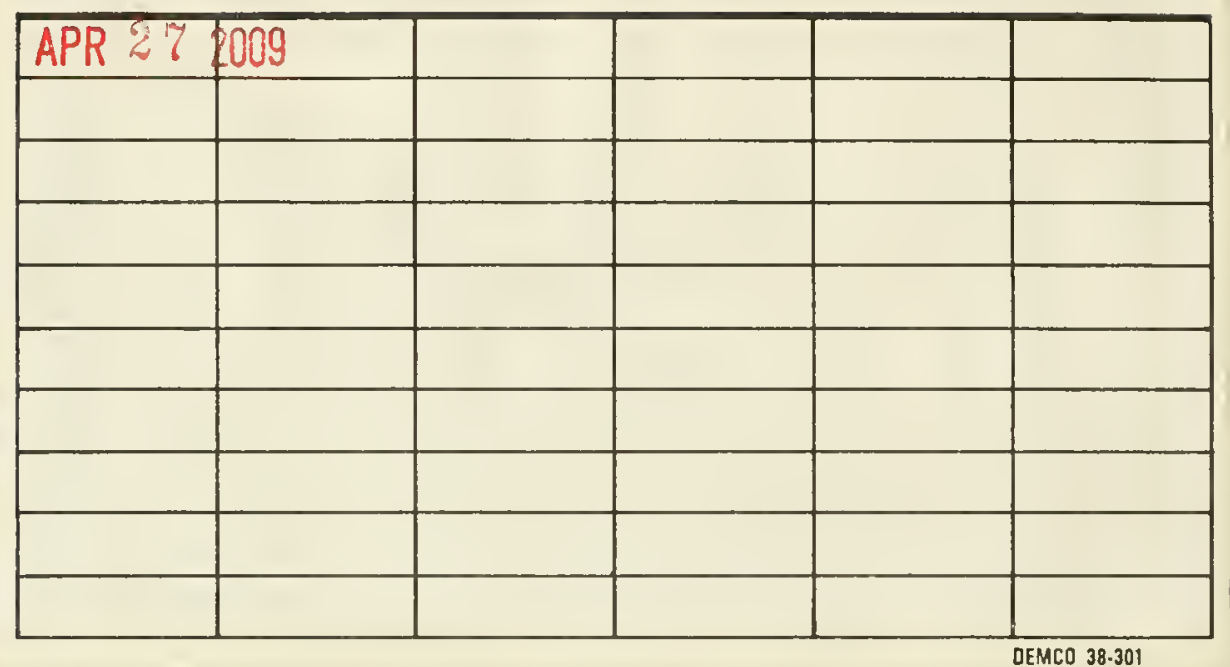


TABLE OF CONTENTS

REPORT CITATION FORMAT

EXECUTIVE SUMMARY

BY STEVEN VIGG

- The Problem of Salmon Poaching and Habitat Loss

- The Law Enforcement Entities and Jurisdictions

- The Rationale for the Columbia Basin Law Enforcement Program

- The Goal Scope, and Approach of the BPA-funded Enhanced Law Enforcement Program

- BPA-Enhanced Law Enforcement Personnel, Equipment, and Budgets 1992-1994

- Performance Criteria, Enforcement Statistics, and Biological Objectives

- Adaptive Management and Program Direction

CHAPTER 1. COLUMBIA RIVER INTER-TRIBAL FISH COMMISSION BY CAPTAIN JOHN JOHNSON AND LT. JERRY EKKER

1.1 Introduction

1.2 Enhancements during Demonstration Period versus 1991 Baseline

1.3 Coordination

1.4 Current Methods for Enforcement Data Collection and Management

1.5 Results

1.6 Public Education and Awareness

1.7 Evaluation Plan

1.8 Adaptive Management and Future Project Improvements

Chapter 2. Oregon Department Of State Police BY CAPTAIN LINDSAY BALL AND LT. ROGER TUERS

2.1 Introduction

2.2 Enhancements during Demonstration Period versus 1991 Baseline

2.3 Current Methods for Enforcement Data Collection and Management

2.4 Results

2.5 Evaluation Plan

2.6 Adaptive Management and Future Project Improvements

Chapter 3. WASHINGTON DEPARTMENT OF FISH AND WILDLIFE BY CHIEF DAYNA MATHEWS

3.1 Introduction

3.2 Personnel

3.3 Screening Violations -- Benton and Klickitat Counties

3.4 Results 
3.5 Evaluation of the Law Enforcement Program

3.6 Adaptive Management -- Programmatic Changes Required During 1995

CHAPTER 4. IDAHO DEPARTMENT OF FISH AND GAME

BY CHIEF FRANK NESMITH

4.I Introduction

4.2 Enhancements during Demonstration Period versus 1991 Baseline

4.3 Current Methods for Enforcement Data Collection and Management

4.4 Results

4.5 Public Education and Awareness

4.6 Evaluation Plan

4.7 Adaptive Management and Future Project Improvements

Chapter 5. NATIONAl MARINe Fisheries Service

BY DAVID A. MCKINNEY AND ROD L. MOXLEY

5.1 Introduction

5.2 Enhancements during Demonstration Period versus 1991 Baseline

5.3 Current Methods for Enforcement Data Collection and Management

5.4 Results

5.5 Evaluation Plan

5.6 Adaptive Management and Future Project Improvements

Chapter 6. Montana Department of Fish, Wildlife and Parks BY CAPTAIN MACK LONG

6.I Introduction

6.2 Current Methods for Enforcement Data Collection and Management

6.3 Results

6.4 Evaluation Plan

6.5 Adaptive Management and Future Project Improvements

APPENDIX 1. REFERENCES

APPENDIX 2. SUMMARY OF ANADROMOUS AND RESIDENT FISH SPECIES IN THE COLUMBIA BASIN THAT ARE LISTED, PETITIONED, OR POTENTIAL CANDIDATES UNDER THE ENDANGERED SPECIES ACT, AS OF 1994

ApPendix 3. List of Presentations, Publications and News Releases

APPENDIX 4. THE COLUMBIA RIVER INDIVIDUAL ACTIVITY REPORT DEVELOPED BY OREgON STATE POLICE 


\section{DisClaIMER}

This report was funded by the Bonneville Power Administration (BPA), U.S. Department of Energy, as part of BPA's program to protect, mitigate, enhance, and recover fish and wildlife affected by the development and operation of the hydroelectric facilities on the Columbia River and its tributaries. The views presented in this report are the authors and do not necessarily represent the views of BPA.

\section{ACKNOWLEDGMENTS}

The enhanced law enforcement program was conceived by regional consensus in the 1990-1991 Salmon Summit initiated by Senator Mark Hatfield. The conceptual plan for developing the multi-agency basin-wide enforcement program was a result of input from the Directors of the fishery agencies from Oregon, Washington, Idaho, and Columbia River Inter-Tribal Fish Commission -- in conjunction with Bonneville Power Administration management, i.e., Jack Robertson, former acting Administrator, and John Palensky, former director of the Fish and Wildlife Division. The original implementation plan (Vigg 1991) was an integration of four individual Statements of Work provided by the Law Enforcement managers of the participating enforcement entities -- Captain John Johnson (Columbia River Inter-Tribal Fish Commission, CRITFC), Chief Dayna Matthews (Washington Department of Fish and Wildlife, WDFW), Major Roy Hyder (Oregon Department of State Police, OSP), and Chief Frank NeSmith (Idaho Department of Fish and Game, IDFG). Subsequently, the National Marine Fisheries Service (NMFS), and Montana Department of Fish Wildlife \& Parks (MDFWP) have been incorporated into the BPA-funded program. All member agencies of the Columbia Basin Law Enforcement Council (CBLEC) -- NMFS, U.S. Fish and Wildlife Service (USFWS), OSP, WDFW, DFG, CRITFC, MDFWP, Shoshone Bannock Tribes (SBT), and the U.S. Coast Guard (USCG) -- are now providing active participation and coordination for the BPA-funded enhanced Columbia Basin law enforcement program. The chapters of this report are written by the project leaders of the six law enforcement agencies funded by BPA's enhanced law enforcement Project 92-024. The report was edited by BPA for consistent format, not to change the interpretation of the data or the conclusions of the respective authors.

\section{REPORT CITATION FORMAT \\ Citation of this BPA Final Report:}

Vigg, S. (editor). 1995. Increased levels of harvest \& habitat law enforcement and public awareness for anadromous salmonids and resident fish in the Columbia River Basin -Project 92-024 Final Report for the demonstration period, 1992-94. June 31, 1995. Bonneville Power Administration, Portland, Oregon.

\section{Citation of a specific Chapter in this BPA Final Report:}

Author(s). 1995. Chapter Title. Pages xx to xx in: Increased levels of harvest \& habitat law enforcement and public awareness for anadromous salmonids and resident fish in the Columbia River Basin -- project 92-024 Final Report for the demonstration period, 199294 (S. Vigg, editor). June 31, 1995. Bonneville Power Administration, Portland, Oregon. 


\section{Digitized by the Internet Archive in 2011 with funding from Montana State Library}




\title{
Executive Summary
}

\author{
SteVen VigG, Fishery Biologist
}

Bonneville Power Administration

Fish and Wildlife Division -- EWN

P.O. Box 3621

Portland Oregon 97208-3621

\section{The Problem of Salmon Poaching and Habitat Loss}

Illegal take of salmon and other depressed fish stocks is a regional, national, and international problem. Illegal harvest and violation of habitat protection regulations are factors affecting the survival of many native species of anadromous and resident fish in the Columbia Basin. The extent of the poaching impacts on fishery resources, however, extends far beyond the region's boundaries. Musgrave et al. (1993) conducted a nation-wide survey of the status of poaching and interviewed many state and federal law enforcement professionals concerning the problems and solutions. All enforcement officials agreed that increased enforcement efforts combined with public education were needed to increase compliance with fish and wildlife laws. Poaching is also an international problem. Poorly regulated high seas gill net drift fisheries have illegally taken millions of salmon annually during the past decade. For example, the illegal 1988 harvest was estimated to be $\mathbf{5 . 5}$ million salmon weighing 10,000 metric tons (Pella et al. 1993). Thus this illegal ocean take was over twice the total salmonid run into the Columbia River. This problem has only recently been addressed with the passage of the United Nations Convention on the Law of the Sea and the establishment in 1993 of the North Pacific Anadromous Fish Commission (NPAFC) with law enforcement oversight and monitoring. However the problem of illegal take -through poaching and habitat alteration -- is still pervasive throughout the life cycle of Pacific salmon.

\section{The Law Enforcement Entities and Jurisdictions}

In the Columbia Basin Region the primary fishery management entities with enforcement jurisdiction are the four states (Montana, Idaho, Washington, and Oregon), the Inter-Tribal Fish Commission representing the four Treaty Tribes (Yakima, Warm Springs, Nez Perce, and Umatilla) in Zone 6 of the mainstem, and individual tribes in reservations and ceded lands encompassing tributary areas. According to Musgrave et al. (1993): "Federal lows for protection of wildlife, such as the Lacy Act and the Endangered Species Act, provide some muscle to enforcement, but it is largely the states that must bear the brunt of enforcement of wildlife laws." Primary responsibility for enforcement of federal and inter-state fishery regulations is held by the U.S. Fish and Wildlife Service (USFWS), the National Marine Fisheries Service (NMFS), and the U.S. Coast Guard (USCG). NPAFC, composed of the United States, 
Canada, Japan, and Russia, enforces the ban on directed fishing on anadromous salmonids beyond the 200-mile zone in the North Pacific.

\section{The Rationale for the Columbia Basin Law Enforcement Program}

The impetus for initiating this enhanced law enforcement program, funded by Bonneville Power Administration (BPA), is to provide additional protection for critically depleted stocks that are listed or proposed for listing under the federal Endangered Species Act of $1973^{1}$ (Appendix 2). Under Section 7(a)(1) of the ESA, Federal agencies are mandated "... to utilize their authorities, in furtherance of the purposes of this Act by carrying out programs for the conservation of endangered species and threatened species listed pursuant to section 4 of this Act." The ESA specifically lists law enforcement as one of the conservation measures to be used to rebuild threatened or endangered species to achieve de-listing (Section 3(3)). The National Marine Fisheries Service (NMFS) is the federal agency responsible for conducting the ESA process (biological status reviews, proposed listings, determination of threatened or endangered status, and Section $7 \& 10$ consultations) for anadromous salmonids in the Columbia Basin. In contrast, the parallel ESA process for resident fish is conducted by the U.S. Fish and Wildlife Service (USFWS).

\section{The Goal Scope, and Approach of the BPA-funded Enhanced Law Enforcement Program.}

Goal. The goal of this system-wide Law Enforcement Program is to reduce illegal takes ${ }^{2}$ of Columbia River Basin salmonids and native resident fish, and thereby help to rebuild of all endemic fish populations within the basin. Illegal take includes the following activities: illegal harvest of adults and juveniles, harassment of spawners attending redds, destruction eggs or fry within redds, direct mortality of juveniles caused by various human activities (e.g., water diversion), and degradation of critical habitat. Specific goals and objectives of the cooperators are detailed in the BPA Statements of Work (Vigg 1991, 1994) and are consistent with this overall goal. This report describes the structure of the law enforcement program, the cooperation among the participants, and the specific work performed under BPA funding. The project was designed as an integrated inter-agency program, and it in no way affects the sovereign rights, jurisdictions, or policy positions of the participating agencies and tribes.

Scope. The conceptual scope of the overall program is the entire life cycle of the target fish species, i.e., "gravel to gravel". The geographical scope of the BPA-funded program is the entire Columbia River Basin, including near shore ocean, estuary, mainstem, and tributaries. With the cooperation and support of the NMFS and U.S. Coast Guard, the geographic scope of enhanced law enforcement extends from to the near shore ocean to the high seas. The targeted fish stocks are depleted anadromous salmonids and resident fish species -- especially species petitioned or

The ESA as Amended by P.L. 94-325, June 30, 1976; P.L. 94-359, July 12, 1976; P.L. 95-212, December 19, 1977; P.L. 95-632, November 10, 1978; and P.L. 96-159, December 28, 1979. kill, trap, capture, or collect, or to attempt to engage in any such conduct." 
listed under the ESA. It is expected that enhanced protection will also extend to all other endemic fish populations in the Columbia Basin (e.g., steelhead, and white sturgeon); this enhancement "spin-off" is considered by all participants to be beneficial to fishery resource of the entire region.

Approach. The approach we are taking is threefold. First, to substantially increase and maintain the levels of harvest and habitat law enforcement throughout the Columbia Basin -- to more than double pre-program (1991) baseline conditions for all state and tribal enforcement agencies. Secondly, to enhance the efficiency of this increased enforcement effort by promoting cooperation and assistance from appropriate federal, state, tribal, regional and local entities. Thirdly, to educate the public on the plight of specific fish stocks that are in danger of extinction and the need to protect their critical habitats; and make the public aware of the importance to society of conserving the cultural values and diversity of anadromous salmonid species and resident fish for future generations.

\section{BPA-Enhanced Law Enforcement Personnel, Equipment, and Budgets 1992-1994}

Personnel. The BPA-funded project (\#92-24) has increased the number of Columbia Basin law enforcement officers from 26 in 1991 to 60 in 1994 (Table 1). These additional enforcement personnel more than doubled the law enforcement effort in the Columbia Basin, i.e., it constitutes an increase of $131 \%$ over baseline levels.

Table 1. Increased levels of fisheries harvest law enforcement personnel (FTE) in the Columbia and Snake river basins derived from BPA funding, 1992-1994 (Vigg 1994).

\begin{tabular}{|c|l|l|l|l|}
\hline AGENCY & $\begin{array}{l}\text { 1991 BASELINE } \\
\text { PERSONNEL IN } \\
\text { THE COLUMBIA } \\
\text { \& SNAKE } \\
\text { RIVER BASINS }\end{array}$ & $\begin{array}{l}\text { ADDITIONAL } \\
\text { BPA FUNDED } \\
\text { FTE FOR 1992 } \\
\text { (OVER 1991 } \\
\text { BASELINE) }\end{array}$ & $\begin{array}{l}\text { ADDITIONAL } \\
\text { BPA FUNDED } \\
\text { FTE FOR 1993 } \\
\text { (OVER 1991 } \\
\text { BASELINE) }\end{array}$ & $\begin{array}{l}\text { ADDITIONAL } \\
\text { BPA FUNDED } \\
\text { FTE FOR 1994 } \\
\text { (OVER 1991 } \\
\text { BASELINE) }\end{array}$ \\
\hline CRITFE & 14 & 5 & 8 & 8.5 \\
\hline OSP & 5 & 6 & 7.5 & 7.5 \\
\hline WDFW & 5 & 7 & 10.5 & 10.5 \\
\hline IDFG & 2 & 5 & 5.75 & 7 \\
\hline Total & 26 & 23 & 31.75 & 33.5 \\
\hline
\end{tabular}

Equipment. The BPA funding provided each participating agency with: sophisticated electronic and surveillance equipment (e.g., night vision, radio-tracking, and FLIR); specialized vehicles and boats; airplanes; weapons; data management systems; communications; back country gear; and field stations -- that were not previously attainable due to inadequate enforcement funding. Because the diverse geography and special circumstances throughout the Columbia Basin, each enforcement entity had needs for specialized equipment. The non-expendable and capital improvements provided by BPA funding are available in inventory reports submitted to BPA. 
Budgets. During the demonstration period, the total cost of the program was about $\$ 12$ million (Table 2). Thus the average annual amount of BPA funding was about $\$ 4$ million during 1992 1994.

Table 2. Actual annual expenditures of the Law Enforcement Program during the Demonstration Period (calendar years 1992-1994) and the amount obligated for 1995 (Vigg 1994).

\begin{tabular}{|c|c|c|c|c|c|c|}
\hline Component & $\begin{array}{l}1992 \\
\text { (including } \\
\text { pre-award) }\end{array}$ & 1993 & 1994 & $\begin{array}{l}\text { Three-Year } \\
\text { Total }\end{array}$ & $\begin{array}{c}1995 \\
\text { Obligated }\end{array}$ & $\begin{array}{l}\text { Four-Year } \\
\text { Total }\end{array}$ \\
\hline $\begin{array}{l}\text { 92-024-01 } \\
\text { CRITFC }\end{array}$ & $\$ 1,210,195$ & $\$ 1,220,466$ & $\$ 909,422$ & $3,340,083$ & $\$ 1,093,492$ & $\$ 4,433,575$ \\
\hline $\begin{array}{l}\text { 92-024-02 } \\
\text { OSP }\end{array}$ & 921,589 & 901,107 & 783,467 & $2,606,163$ & 874,789 & $3,480,952$ \\
\hline $\begin{array}{l}92-024-03 \\
\text { WDFW }\end{array}$ & $1,273,283$ & $1,238,002$ & 860,864 & $3,372,149$ & 872,778 & $4,244,927$ \\
\hline $\begin{array}{l}92-024-04 \\
\text { IDFG }\end{array}$ & 693,283 & 842,217 & 671,340 & $2,206,840$ & 637,317 & $2,844,157$ \\
\hline $\begin{array}{l}92-024-05 \\
\text { NMFS }\end{array}$ & 0 & $59,451^{\text {a. }}$ & 31,131 & 90,582 & $7,347^{b}$ & 97,929 \\
\hline $\begin{array}{l}\text { 92-024-06 } \\
\text { MDFWP }\end{array}$ & 0 & 0 & $25,000^{\mathrm{c}}$ & 25,000 & 61,757 & 86,757 \\
\hline FLIR & $392,339^{d .}$ & 0 & 0 & 392,339 & 0 & 392,339 \\
\hline $\begin{array}{l}\text { 92-024-07 } \\
\text { Evaluation }\end{array}$ & 0 & 0 & 0 & 0 & $(250,000)^{\text {e. }}$ & 0 \\
\hline TOTAL & $\$ 4,490,689$ & $\$ 4,261,243$ & $\$ 3,250,093$ & $\$ 12,033,156$ & $\$ 3,578,611$ & $\$ 15,580,636$ \\
\hline
\end{tabular}

a. This amount includes funding for a 3 -year building lease (4/4/93 to 4/3/96) with Columbia Business Center and associated utilities funded directly by BPA $(\$ 59,451)$.

b Amount does not include \$31,131 that was carried forward from 1994 to 1995.

c. Montana LE funding in 1994 was through resident fish project.

d. Forward-Looking Infra-Red system (FLIR) funding was provided to WDFW $(\$ 261,559)$ and to OSP $(\$ 130,780)$.

e. Evaluation funding of $\$ 250,000$ planned for 1995 was deferred to FY1996 funding.

\section{Performance Criteria, Enforcement Statistics and Biological Objectives}

\section{Performance Criteria}

Ultimately, the success of the enhanced LE program will be measured achievement of its primary goals and objectives. Namely, significant decreases in the illegal take of anadromous salmonids and other depressed fish species throughout the Columbia Basin, and increased public awareness of the importance of conserving this fishery resource. The evaluation of the efficacy of the increased law enforcement effort will be difficult to measure, and must be judged by taking different perspectives into consideration. Vigg (1991) identified the following evaluation 
perspectives: (a) deterrents caused by publicity and visibility of the program and expectation of apprehension, (b) enforcement statistics, and (c) fishery statistics.

Specific criteria to judge success include:

1. publicity, in various media, on the size and extent of the program;

2. awareness of the public that law enforcement is greatly increased on Columbia and Snake river salmon runs;

3. overt presence measured by increased numbers of uniformed officers in the field and total time spent on patrol;

4. increased utilization of sophisticated communications and surveillance capabilities (ground, water, air) of the law enforcement force;

5. increased use of inter-agency coordination and saturation task forces where problems exist (e.g., following the runs from the estuary to tributaries);

6. increased number of arrests;

7. increased number and percent of prosecutions, fines, and jail terms;

8. increased equipment and fish seized;

9. decreased market availability of illegal salmon as measured by covert operations;

10. ability to estimate the extent of illegal harvest of salmon and steelhead throughout the Columbia Basin;

11. decreased inter-dam loss that is attributable to decreased illegal harvest; and

12. increased numbers of adult spawners escaping to spawning areas.

\section{Law Enforcement Statistics}

Summary enforcement statistics demonstrate a high level of enforcement effort was maintained during 1992-94, i.e., an average of about 28,000 patrol hours and 37,000 public contacts per year (Table 3). A consistent trend of decreasing arrests during the three year period occurred in each jurisdiction; this trend indicates increased public awareness and effectiveness of the enhanced law enforcement program in deterring illegal activity. The increasing deterrence trend is also quantified by the improved compliance index measured during 1992-1994. In Oregon, compliance was $78.5 \%, 83.4 \%$, and $89.5 \%$ during 1992, 1993, and 1994, respectively (OSP, Chapter 2). In Idaho, compliance was $93.1 \%, 95.7 \%$, and 96.4\% during 1992, 1993, and 1994, respectively (IDFG, Chapter 4). 
Table 3. Enforcement statistics (contacts, arrests, patrol hours) by agency, 1992-1994 (Data are derived from Chapters $1-4$ of this report).

\begin{tabular}{|c|c|c|c|}
\hline $\begin{array}{l}\text { LAW ENFORCEMENT ENTITY / } \\
\text { Statistic }\end{array}$ & 1992 & 1993 & 1994 \\
\hline \multicolumn{4}{|l|}{$\begin{array}{l}\text { COLUMBIA RIVER INTER-TRIBAL } \\
\text { FISH COMMISSION }\end{array}$} \\
\hline Contacts & 1,395 & 3,771 & 8,088 \\
\hline Tribal Arrests & 49 & 25 & 29 \\
\hline Enforcement Hours & 9,323 & 10,287 & 10,743 \\
\hline \multicolumn{4}{|l|}{ OREGON } \\
\hline$\overline{\text { Contacts }}$ & 11,955 & 8,584 & 10,026 \\
\hline Arrests & 1,019 & 515 & 447 \\
\hline Enforcement Hours & 18,772 & 18,616 & 20,742 \\
\hline \multicolumn{4}{|l|}{ WASHINGTON } \\
\hline Contacts & 14,653 & 18,270 & 13,886 \\
\hline Arrests & 714 & 1,120 & 780 \\
\hline Enforcement Hours & 9,956 & 12,028 & 7,856 \\
\hline \multicolumn{4}{|l|}{$\underline{\text { IDAHO }}$} \\
\hline Contacts & 6,840 & 7,369 & 5,874 \\
\hline Arrests & 313 & 245 & 152 \\
\hline Enforcement Hours & 7,142 & 8,403 & 6,877 \\
\hline
\end{tabular}

The combined Columbia Basin statistics show that the enforcement effort has more than doubled from the 1990 baseline (about 15,000 patrol hours) to over 32,000 patrol hours per year during 1992-94 (Table 4). The deterrent effect of enhanced enforcement is clearly illustrated by increased effort and arrests (from the baseline to demonstration period) compared to a consistent decreasing trend of illegal nets and salmon seized (Figure 1).

Table 4. Enforcement statistics throughout the Columbia Basin (ocean excluded) all LE agencies combined, 1992-1994 (source Captain John Johnson, CRITFC; NMFS data base).

\begin{tabular}{|l|r|r|r|r|}
\hline Statistic & $\begin{array}{l}\text { 1990* } \\
\text { Baseline' }\end{array}$ & \multicolumn{1}{|l|}{1992} & \multicolumn{1}{l|}{1993} & \\
\hline Enforcement Hours & $\mathbf{1 5 , 1 1 2}$ & $\mathbf{3 2 , 4 4 3}$ & $\mathbf{3 7 , 3 7 2}$ & $\mathbf{3 2 , 7 5 6}$ \\
\hline Commercial Arrests & 135 & 113 & 113 & 60 \\
\hline Sport Arrests & 618 & 1,633 & 1,702 & 1,330 \\
\hline Total Arrests & $\mathbf{7 5 3}$ & $\mathbf{1 , 7 4 6}$ & $\mathbf{1 , 8 1 5}$ & $\mathbf{1 , 3 9 0}$ \\
\hline Nets Seized & 195 & 196 & $\mathbf{1 5 1}$ & $\mathbf{9 6}$ \\
\hline Salmon Seized & $\mathbf{3 9 5}$ & $\mathbf{2 8 5}$ & $\mathbf{2 4 1}$ & $\mathbf{6 8}$ \\
\hline
\end{tabular}

1. Enforcement data collection was suspended in 1991 due to lack of funds, then reactivated when the BPA LE Program was implemented in 1992. 


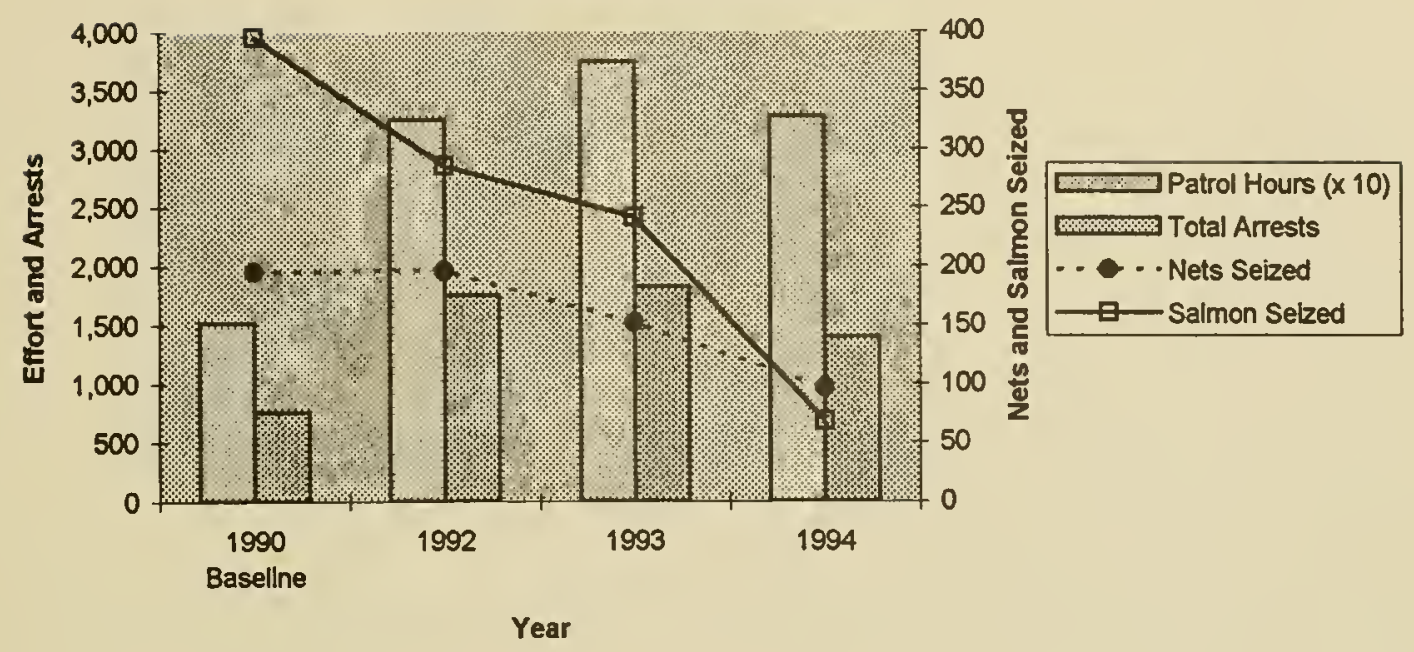

Figure 1. Trends in total Columbia Basin enforcement statistics showing increased effort (patrol hours) and increased arrests -- corresponding to decreased illegal nets and salmon seized during 1992-94 compared to the 1990 baseline.

\section{Increased Survival of Juvenile Salmon -- Habitat Protection}

One specific biological objective is improvement in juvenile salmon survival by protection of critical habitat during rearing and protection from illegal diversions during downstream migration through the Columbia and Snake rivers (Vigg 1994). Although fishery harvest enforcement has been the primary focus of the BPA-funded program, habitat enforcement has been recognized by CBLEC as an important enhancement to the program. In 1993, increased habitat enforcement was initiated in cooperation with various regulatory agencies. Habitat enforcement activities included identification and prosecution of illegal irrigation diversions, stream alterations, and watershed degradation -- refer to John Harrison's (1993) interview with Captain Lindsay Ball, OSP Fish and Wildlife Division Director.

The problem of direct mortality to juvenile salmonids caused by insufficient screens on mainstem Columbia and Snake River pump stations was identified by NMFS 14 years ago, but was ignored until recently. Some of the conclusions from the previous a BPA-funded study conducted by George Swan $(1980,1981,1982)$ were that:

"Poorly maintained or inadequate screening could have serious impact on small or larval stage fishes." ... "Repeated inspections of screening facilities by fisheries agencies have pointed out a need for enforcement of proper fish protection standards."... "After completion of our 2 year study it is apparent that the screening program for withdrawals as currently managed is not in the best interests of fish production or fish protection." ... "A program of anmual surveillance and 
monitoring of water withdrawals to ensure that fish protective facilities at withdrawals remain within the acceptable criteria. ... This program should be conducted by an agency with the authority to enforce the conditions of the permits." A mainstem Columbia River irrigation pump station survey was initiated which brought to light the fact that the problems Swan (1982) identified were still in effect in 1993 (Lt. Larry Kraft, OSP Personal Correspondence, 1993). Storment-Ray (1993) found that the number of pumping sites increased from 205 in 1980 to 709 in 1993 -- with a great increase in pump capacity as well as number. A high non-compliance rate of screening requirements to protect fish existed in 1981 (over 60\%) and non-compliance continued through 1993, i.e., about $83 \%$ in Oregon (Chris Inc. 1994). The law enforcement initiative resulted in a follow-up study in Washington and the provision of about $\$ 100,000$ in Mitchell Act funds. The Washington component of the irrigation pump station screen compliance program has found the following (Ken Bates, WDFW, memos dated 8/15/94 and 12/13/94): (1) about 400 irrigation, municipal and industrial intakes exist above Bonneville on the Columbia and Snake rivers, within the state of Washington; (2) a number of large intakes exist on the Okanogan River -- many just downstream of important summer chinook spawning areas; (3) about $77 \%$ of the mid-Columbia sites inspected were out of compliance.

The result of the screening activities in Oregon and Washington has been to increase compliance from less than $33 \%$ when the survey was conducted in $1992-93$ to nearly $100 \%$ in 1994 (Chapters 2 and 3). All violators have either complied or are actively participating in programs to bring screens into compliance. Cooperation between the enforcement programs, habitat programs, and water diverters contributed significantly to the direct protection of the juvenile salmon in the affected areas.

\section{Increased Survival of Adult Salmon -- Inter-Dam Conversion Rates}

Another specific biological objective is improvement in adult salmon survival during upstream migration through the Columbia and Snake rivers (Vigg 1994). Monitoring changes in previously unaccounted losses in migrating salmonid populations and analyzing inter-dam conversion rates ${ }^{3}$ provides a basis for quantitative evaluation of this objective. The results to date show increases in conversion rates during 1992-94 (Figure 2). A longer term data base and a more rigorous analysis is needed, however, to show a cause-effect relationship between increased enforcement and improved adult survival. Factors such as environmental variability, environmental conditions in the ocean and freshwater phases of the life cycle, and other mitigation actions must be taken into account.

\footnotetext{
${ }^{3}$ Conversion rates arc a measure of adult salmon survival between specified river reaches between dams; for cxample -- Bonneville to McNary, McNary to Ice Harbor, Ice Harbor to Lower Granite, or Bonneville to Lower Granite. Inter-dam conversion rates are calculated as the ratio of the adult salmon counts at the upriver dam / downriver dam -- after all known mortalities and turnoffs (c.g., harvest mortalities, hatchery returns, and tributary turnoffs) have been accounted for. The inverse of inter-dam conversion rate is known as unaccounted inter-dam loss.
} 


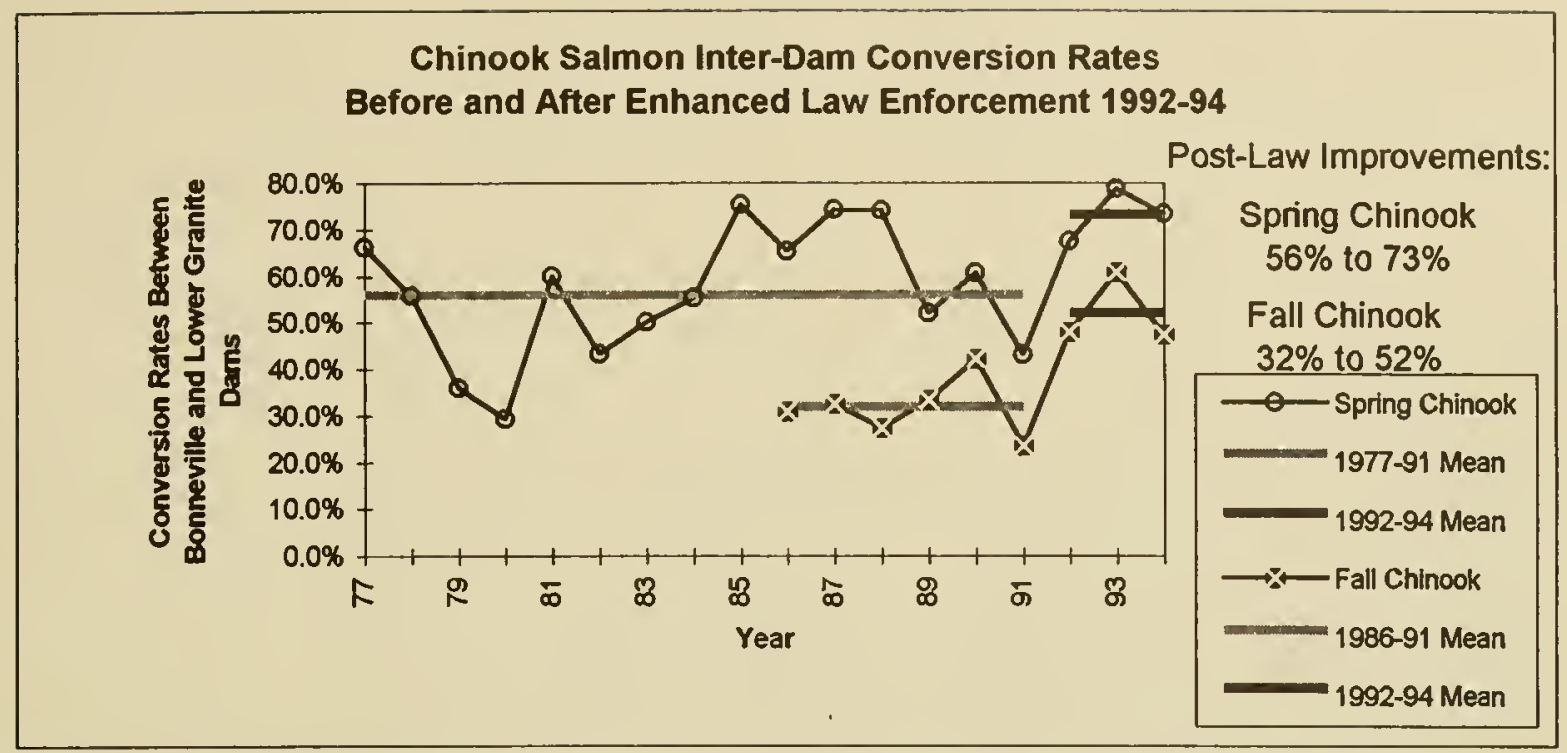

Figure 2. Conversion rate of adult spring and fall chinook runs between Bonneville and Lower Granite Dams, 1977-1994.

During 1992-94, the first three years of implementation of the Law Enforcement Program, the Bonneville to Lower Granite dam conversion rates improved substantially over the previous average baseline of $56.0 \%$ for spring chinook salmon and $31.6 \%$ for fall chinook salmon (Table 5). For fall chinook salmon, these inter-dam conversion rates were at record-breaking high levels during all three years after enhanced law enforcement was initiated, i.e., a range of $47-61 \%$ for 1992-94 compared to a range of $24-42 \%$ for $1986-91$. The mean $1992-94$ conversion rate of $52 \%$ for fall chinook salmon constitutes a $53 \%$ increase -- compared to the previous period. Similarly for upriver spring chinook salmon, the Bonneville to Lower Granite inter-dam conversion rate in 1993 was the highest on record (79\%). For spring chinook, the 1992-94 mean conversion rate $(73 \%)$ was $29 \%$ higher than the previous 15 -year mean (56\%). Thus the pattern was consistent for both spring and fall chinook runs -- substantially higher mean conversion rates for the three years after BPA law enforcement compared to the pre-enhancement period of record. 
Table 5. Inter-dam conversion rates (Bonneville to Lower Granite dams) for spring and fall runs of chinook salmon, 1977-94; mean conversion rates before and after implementation of the BPA- funded enhanced law enforcement program are presented.

\begin{tabular}{|c|c|c|}
\hline Year & Spring Chinook & Fall Chinook \\
\hline $\mathbf{1 9 7 7}$ & 0.66 & \\
\hline $\mathbf{1 9 7 8}$ & 0.56 & \\
\hline $\mathbf{1 9 7 9}$ & 0.36 & \\
\hline $\mathbf{1 9 8 0}$ & 0.29 & \\
\hline $\mathbf{1 9 8 1}$ & 0.60 & \\
\hline $\mathbf{1 9 8 2}$ & 0.43 & \\
\hline $\mathbf{1 9 8 3}$ & 0.50 & \\
\hline $\mathbf{1 9 8 4}$ & 0.55 & \\
\hline $\mathbf{1 9 8 5}$ & 0.75 & \\
\hline $\mathbf{1 9 8 6}$ & 0.65 & 0.31 \\
\hline $\mathbf{1 9 8 7}$ & 0.74 & 0.32 \\
\hline $\mathbf{1 9 8 8}$ & 0.74 & 0.27 \\
\hline $\mathbf{1 9 8 9}$ & 0.52 & 0.33 \\
\hline $\mathbf{1 9 9 0}$ & 0.61 & 0.42 \\
\hline $\mathbf{1 9 9 1}$ & 0.43 & 0.24 \\
\hline Pre-Law Mean & $\mathbf{0 . 5 6 0}$ & $\mathbf{0 . 3 1 6}$ \\
\hline $\mathbf{1 9 9 2}$ & 0.68 & 0.48 \\
\hline $\mathbf{1 9 9 3}$ & 0.79 & 0.61 \\
\hline $\mathbf{1 9 9 4}$ & 0.73 & 0.47 \\
\hline Post-Law mean & $\mathbf{0 . 7 3 2}$ & $\mathbf{0 . 5 2 0}$ \\
\hline Percent & $\mathbf{2 9 . 1 \%}$ & $\mathbf{5 3 . 3 \%}$ \\
\hline Improvement & & \\
\hline
\end{tabular}

\section{Increased Survival of Resident Fish}

A third biological objective is to enhance the survival of depleted resident fish populations through protection of critical habitat, fishery enforcement, and public outreach. Starting in 1994, BPA provided additional enforcement funding to Montana in order to focus more on resident fish problems (Vigg 1994). The Kootenai River white sturgeon is currently listed as "endangered" and several other depleted resident fish species are under consideration for protection pursuant to the ESA (Appendix 2; Chapter 6).

\section{Adaptive Management and Program Direction}

The concept of iterative program improvements via ongoing monitoring and evaluation (M\&E) followed by program changes based on the derived results is central to the enhanced law 
enforcement program (Vigg 1994). The Snake River Recovery Team stated the need for integrating M\&E in recovery actions (Bevan et al. 1994): "Monitoring must be carried out and results presented in a timely and scientifically sound manner for evaluation. Furthermore, monitoring results must provide a strong input to management decisions on recovery actions, so that needed adjustment can be applied."

The LE grants were initially set up as a three year demonstration project (i.e., 1992-94) -- with its continuation dependent upon an independent evaluation of the efficacy of the enhanced LE in protection of depleted fish stocks in the Columbia Basin (Vigg 1991). However, funding was not available to conduct a comprehensive evaluation during the initial three years. The BPA funding was continued in 1995 based on a preliminary analysis of results presented to the NMFS Snake River Salmon Recovery Team (Memo from S. Vigg to Rob Jones, NMFS dated December 16, 1993), favorable recommendations from the Recovery Team (Bevan et al. 1994), and regional support from directors of the cooperating fisheries agencies and tribes (letter from six agency directors to Randy Hardy, BPA dated June 27, 1994). At this time, a comprehensive evaluation of the efficacy of the program in achieving its specific objectives and the overall goal of enhancement of depleted fish stocks is required -- in order to be accountable for achieving desired results from expenditures, to adaptively manage the program, and to ensure cost-effectiveness. 
Chapter 1. Columbia River Inter-Tribal Fish Commission -- Project 92-024-01

\author{
Captain John B. Johnson, Law Enforcement Dept. Manager \\ Jerry M. Ekker, Lt. In Charge of Operations \\ Columbia River Inter-Tribal Fisheries Enforcement \\ 4270 Westcliff Drive \\ Hood River, Oregon 97031
}

\title{
1.1 Introduction
}

In 1978, the National Marine Fisheries Service, United States Fish and Wildlife Service, Oregon State Police, Washington Department of Fish and Wildlife and Idaho Department of Fish and Game formed the Columbia Basin Law Enforcement Council (CBLEC). CBLEC was formed so the regional fisheries enforcement agencies would have a forum in which to coordinate fisheries enforcement on the Columbia River. CBLEC membership consisted of command personnel from each of the participating agencies. In 1983, the Columbia River Inter-Tribal Fish Commission's Enforcement Department joined CBLEC. From 1978 until the fall of 1991, coordination and levels of enforcement were severely restricted due to a shortage of enforcement resources.

In the summer of 1991, CBLEC, working in partnership with the Bonneville Power Administration (BPA), collectively prepared and submitted law enforcement funding proposals to the BPA. The impetus for initiating these proposals was to provide addendum funding to participating CBLEC agencies for the purpose of enhancing enforcement capabilities throughout the Columbia Basin.

In the fall of 1991, the BPA provided "startup" funding that would initiate a three-year BPA funded, enhanced law enforcement program (1992-1994). This addendum funding gave the participating fisheries enforcement agencies the needed resources to significantly increase enforcement efforts throughout the Columbia Basin. The goal of the project was to provide additional protection for critically depleted stocks that were listed, or proposed for listing, under the Endangered Species Act of 1973. The BPA funding has allowed agencies to significantly increase the numbers of personnel in the field, purchase needed equipment and initiate a proactive public education program for the purpose of increasing the overall effectiveness of enforcement throughout the Columbia Basin. The program was intended to provide a highly visible enforcement presence with the professional capabilities of deterring and detecting violations and arresting offenders. The BPA project was initiated on the premise of "preventative law enforcement" as the best possible methodology for protecting a depleted resource. The program was intended to be aggressive enough to prevent violations from occurring, and over a period of time, promote "voluntary compliance."

1.2 Enhancements during Demonstration Period versus 1991 Baseline 
During the demonstration period (1992-1994), the BPA provided significant resources towards the enhancement of fisheries enforcement throughout the Columbia Basin. During that time, 33 additional fisheries patrol officers were put directly in the field. In addition, a very proactive, aggressive public education program was developed and initiated by Rod Nichols, Conservation Educator for the Idaho Department of Fish and Game. Because of Idaho's experience and recent successes in promoting public education within their own state, the CBLEC agencies agreed that they were best equipped to provide a comprehensive public education program that would represent the interests of all CBLEC agencies. The success of this aggressive approach to "preventative enforcement" through a combination of increased enforcement and public education will be discussed in detail in Section 1.4 Results.

During the demonstration period 1992-1994, the Columbia River Inter-Tribal Fisheries Enforcement Department (CRITFE) received a total of $\$ 3.2$ million dollars for the purpose of adding additional personnel, purchasing needed equipment and to provide other enhancements to increase enforcement productivity. This funding allowed CRITFE supervisors to focus their total efforts towards implementation of the BPA enhanced enforcement program while at the same time, putting additional personnel in the field (see Table 1.2). CRITFE was also able to purchase state-of-the-art equipment (refer to Attachment A) to allow patrol officers to more effectively perform fisheries enforcement responsibilities, both in the field and administratively. In 1994, CRITFE was able to lease office space in the Boardman area for the purpose of boat storage. This capability places a patrol boat upriver at all times in contrast with having to tow a boat upriver from the Hood River CRITFE office. The longer range plan concerning this office is to equip it such that it will serve as a satellite office (telephone, fax, computers, etc.) available for use by all CBLEC participating agencies and particularly officers from other agencies who reside in that area (OSP, WDFW).

Table 1. 1. BPA Budget for Columbia River Inter-Tribal Fish Commission, 1992-1994.

\begin{tabular}{|c|c|c|c|}
\hline Quarter & $\mathbf{1 9 9 2}$ & $\mathbf{1 9 9 3}$ & $\mathbf{1 9 9 4}$ \\
\hline January-March & 108,440 & 236,757 & 192,795 \\
\hline April-June & 319,137 & 372,223 & 204,873 \\
\hline July-September & 190,002 & 299,382 & 201,450 \\
\hline October-December & 517,299 & 272,217 & 325,690 \\
\hline Annual Total & $\$ 1,134,878$ & $\$ 1,180,579$ & $\$ 924,808$ \\
\hline
\end{tabular}

As mentioned, CRITFE was able to hire additional personnel for implementation of the BPA enhanced enforcement program. In order to get the program on-line as quickly as possible, existing positions were transferred to the BPA contract and those positions were backfilled with field personnel. One position was reclassified from Patrol Officer to Investigator. The Investigator position was initiated for three primary purposes: \#1-To actively work with the 
Special Investigations Unit (formed by OSP and WDFW), \#2-To conduct investigations of incidents occurring both in and out of the Zone 6 Treaty fishing area if it involved enrolled tribal members and \#3-To coordinate public education and information with Rod Nichols, Public Educator for the program, as well as with the Public Information Office of the Columbia River Inter-Tribal Fish Commission.

Table 1.2. Additional BPA-funded law enforcement officers (Full Time Equivalents, FTE) over 1991 baseline in the Columbia Basin, by month 1992-1994.

\begin{tabular}{|c|c|c|c|}
\hline MONTH & 1992 & 1993 & 1994 \\
\hline January & 5 & 8 & 8 \\
\hline February & 5 & 8 & 8 \\
\hline March & 5 & 8 & 8 \\
\hline April & 5 & 8 & 8 \\
\hline May & 5 & 8 & 8 \\
\hline June & 5 & 8 & 8 \\
\hline July & 5 & 8 & 8 \\
\hline August & 5 & 8 & 8 \\
\hline September & 5 & 8 & 8 \\
\hline October & 5 & 8 & 8 \\
\hline November & 5 & 8 & 8 \\
\hline December & 5 & 8 & 8 \\
\hline
\end{tabular}

Table 1.3 Current CRITFE personnel assigned to the BPA-funded law enforcement project.

\begin{tabular}{|ll|}
\hline Name & Position \\
John Johnson & Captain \\
Jerry Ekker & Lieutenant \\
Ted LameBull & Sergeant \\
Don Ellingson & investigator/PR \\
Levi Woods & Patrol Officer \\
Lori Watlamet & Patrol Officer \\
Ida Hatch & Dispatcher \\
Sue MacKenzie & Dispatcher \\
\hline
\end{tabular}


In addition to the Investigator, 5 patrol positions were backfilled immediately (1992) with the addition of another patrol position in 1993 as well as two dispatch positions.

\subsection{Coordination}

As an integral component of the BPA grant contracts, it was essential that the CBLEC agencies carefully coordinate enforcement activity, both at the administrative/supervisory level and the field level. Throughout the summer and fall of 1991 the CBLEC held numerous planning and coordination meetings. CBLEC provided the mechanism for coordination at a command level but it was essential to the success of the program that coordination extend to the field level application. CBLEC divided the entire Columbia Basin (Columbia and Snake River system) into patrol areas. Within each area, CBLEC assigned a responsible agency. The agency responsible for a particular area assigned an Area Sergeant. CBLEC also assigned a Field Enforcement Coordinator. National Marine Fisheries Service, Special Agent Dave Johnson, was assigned the Field Coordinator position. CBLEC meets in regular session and develops enforcement plans for the Columbia Basin. Additionally, the Area Sergeants and the Field Coordinator meet regularly for the same purpose - to develop plans for directed enforcement operations throughout the basin. Enforcement plans are ultimately approved at the CBLEC level (with direct input from the Area Sergeants and Field Coordinator and field personnel). The responsibility of detailed implementation is assigned to the Field Coordinator and Area Sergeants. The development of this comprehensive planning process culminated in the formation of the Columbia Basin Salmon Enforcement Team (CBSET). The CBSET allowed for coordinated, basin-wide enforcement operations. Additionally, each Sergeant was responsible for coordinated joint-agency operations within their particular geographical area, utilizing area personnel. Every operation, outside the norm of "routine patrol" would require a reporting and documentation process historically developed by the Oregon State Police. Following the CBLEC/CBSET planning process, the Area Sergeant in the area of a special operation is required to prepare an Enforcement Action Report (EAR). The EAR would be jointly developed by participating agencies at a supervisory level with direct input from field personnel. This EAR would be a detailed plan of action, specifying resources needed, enforcement strategy, equipment to be utilized, etc. Following implementation of the EAR, an After Action Critique Report (AACR) is required. The AACR would review the success or failure of a particular enforcement operation, determine appropriate changes for future, similar operations and enumerate statistical data relative to the operation. This reporting methodology is required for both basin-wide operations as well as geographically specific areas. A "CBSET enforcement operation" involves the sharing of personnel among the participating fisheries enforcement agencies. An "area specific" operation would be localized, using personnel routinely assigned to the area.

The CBSET concept of sharing personnel and equipment resources among the participating fisheries enforcement agencies allows CBLEC/CBSET to place significant numbers of officers, equipment and effort in a specific problem area anywhere in the Columbia Basin. If an Area Sergeant identifies a particular enforcement problem within his or her area, that cannot be effectively handled by local officers, the Area Sergeant contacts the Field Coordinator and requests additional personnel and equipment from other CBLEC agencies. The Field Coordinator then coordinates the request with other participating agencies, thereby making the necessary 
resources available. This process is well demonstrated by Operation Corliss which occurred in 1993 and a similar operation initiated a year later but during the same time frame. This report goes into more detail on these two operations in Section 1.5 Results. As a result of the CBSET concept, officers from the CBLEC participating areas have assisted in operations throughout the basin (outside of their routine patrol areas). This inter-agency coordination has created significant esprit de corps among officers from all agencies, at all levels of enforcement application.

Additionally, the BPA funding allowed CRITFE to develop a radio system capable of being jointly utilized by all agencies. Presently, all participating agencies have purchased radio equipment that is compatible with the CRITFE system allowing them to utilize a "common frequency" in coordinating patrol operations. All agencies have also purchased inscription coded, programmable hand-held radios. The inscription makes it impossible for anyone to monitor the radio traffic between officers. Agencies have entered into agreements whereas they exchange agency assigned radio frequencies. Participating agencies are subscribed to a common voice mail system so telephonic communication can occur between agencies and officers. This VoiceCom system allows officers from all geographical areas to actually plan coordinated enforcement operations telephonically, without ever having a face-to-face meeting. The VoiceCom system allows officers to communicate statistical data to an the Area Coordinator, Area Sergeant or any field officer assigned the Enforcement Action Report and Critique mentioned earlier. And of course it allows officers from individual agencies enhanced communications within their own departments. This dedication to enhanced communication and coordination has greatly contributed to the successes of the BPA funded law enforcement program.

\subsection{Current Methods for Enforcement Data Collection and Management}

CRITFE was formed in 1983. Since that time, numerous enforcement data collection methods have been utilized, improved upon and expanded. Because of these improvements and expansions, inconsistency from one year to the next has made it difficult to statistically analyze enforcement related trends. New developments in statistical collection stabilized in 1988, allowing the agency to analyze data in a more consistent manner and thereby utilize data analysis to improve actual field enforcement applications. One trend that was specifically noted was the fact that even though CRITFE had not increased in personnel from 1983 - 1991, the workload of the agency had increased significantly. By 1989-1990, the calls for service had increased so significantly that they had to be prioritized because of lack of officer availability. Calls for service increased $69 \%$ from 1989 to 1990 and $108 \%$ from 1988 to 1990 . Officer overtime was out of control and there was no opportunity for proactive enforcement planning. While planning did take place, in application it was generally interrupted - again due to lack of personnel, equipment and other resources. The work hours put such a strain on underpaid patrol officers that turnover was very high. For all practical purposes (as supported by the statistical data trends), CRITFE had joined the ranks of most other enforcement entities, i.e., reactive law enforcement vs. proactive enforcement.

Presently, CRITFE has a fairly organized process for the accurate collection of enforcement statistical data. CRITFE officers are required to complete a Daily Log for every workday. This 
log keeps track of statistics, such as arrests, seizures, contacts, etc. and breaks the officer's time into specific categories. The CRITFE Dispatch Center records all radio activity on the CRITFE Radio Log. Complaints and other calls for service are recorded on the CRITFE Complaint Log and assigned a case number. The internal CRITFE data collection system is presently computerized and fairly comprehensive. For purposes of our participation in CBLEC and CBSET, we complete a data report (CBLEC Report) which is submitted to the National Marine Fisheries Service (NMFS) in Astoria, Oregon. NMFS receives the same type of reports from the other CBLEC agencies and officers. NMFS inputs the data into a data base which tracks statistical data common among the agencies. Each agency is free to collect additional data as needed for internal purposes. CRITFE officer's CBLEC reports are submitted to an administrative assistant who audits them against daily logs and other agency records for accuracy. The necessary corrections are made and the CBLEC reports are sent to NMFS. The administrative assistant transfers combined data from the officer Daily Logs into a monthly statistical report. This report includes all the data categories used for the CBLEC report as well as additional data unique to CRITFE, such as damaged fishing property complaints, fishing equipment thefts, fishing site disputes investigated, etc. The information from the Daily Logs is transferred to an in-house data base program which tracks fish seizures, net seizures, arrest and property seizure dispositions, patrol hours, patrol miles, boat hours, etc. The CRITFE data base breaks the Treaty Fishing Area (Zone 6) into three pools. The three pools are then divided in two - east pool and west pool. Arrests, fish and net seizures can be tracked to the actual river mile where the incident occurred. This allows us to very specifically and accurately pinpoint problem areas and then direct enforcement actions accordingly. The data base also tracks numbers of salmon, steelhead and sturgeon seized live and released, as well as numbers of salmon, steelhead and sturgeon seized dead and the numbers of the dead fish unfit for human consumption (spoiled). Lieutenant Ekker continues the ongoing process to upgrade CRITFE's data bases. With BPA funding, CRITFE was able to enhance its computer system to the degree necessary to eventually have an integrated computerized system that links every aspect of enforcement work performed by the agency. Such a system would electronically organize records and cross-reference data from Officer's Daily Logs, Radio Logs, Complaint Logs, Citations of Arrest, Evidence Records, and Master Name Index (MNI) cards files.

\subsection{Results}

As stated in Section 1.1 Introduction, the goal of CBLEC in implementing the BPA Enhanced Enforcement Program is to create a deterrent effect (i.e., the potential violator develops an expectation that his/her illegal activities will readily be discovered and prosecuted). A highly visible law enforcement presence combined with a comprehensive public education and awareness program prevents violations from occurring, thus providing maximum protection to the resource. Once a resource violation has occurred, even if followed by arrest, the damage to the resource has generally taken place (i.e., the unlawfully taken fish die). With this goal in mind, the CBLEC, in partnership with the BPA, has launched the highly coordinated law enforcement program discussed in Section 1.2 Enhancements, Section 1.3 Coordination. The two graphs on the following page are excellent indicators that the goal of the program is being achieved. These two graphs epitomize what is happening throughout the Columbia Basin. The trends are very much 
the same - enforcement statistics increased dramatically during the first year of the demonstration period (1992) and then began to decrease significantly in 1993 and 1994 - in spite of the fact that effort, in the form of patrol hours, either stabilized or continued to increase.

Table 1.4. Enforcement Statistics in Zone 6, 1992-1994.

\begin{tabular}{|l|r|r|r|}
\hline BPA PROJECT YEAR & \multicolumn{1}{|c|}{1992} & \multicolumn{1}{c|}{1993} & \multicolumn{1}{c|}{1994} \\
\hline Total Area Hours & 9,323 & 10,287 & 10,743 \\
\hline Hours Patrolled Aircraft & 129 & 194 & 13 \\
\hline Inter-Agency Hours & 1,222 & 981 & 822 \\
\hline Investigation Hours & 113 & 194 & 167 \\
\hline Gillnets Seized & 111 & 75 & 43 \\
\hline Hoopnets Seized & 58 & 39 & 40 \\
\hline Setlines Seized & 11 & 0 & 4 \\
\hline Salmon Seized & 142 & 191 & 32 \\
\hline Steelhead Seized & 70 & 61 & 9 \\
\hline Sturgeon Seized & 14 & 21 & 9 \\
\hline Tribal Arrests & 49 & 25 & 29 \\
\hline Arrest Assists & 6 & 33 & 29 \\
\hline Citizen Assists & 98 & 133 & 152 \\
\hline Contacts & 1,395 & 3,771 & 8,088 \\
\hline
\end{tabular}




\section{Special Emphasis Patrols -- Deterrence is Working}

23\% Decrease in Arrests From 1993 to 1994

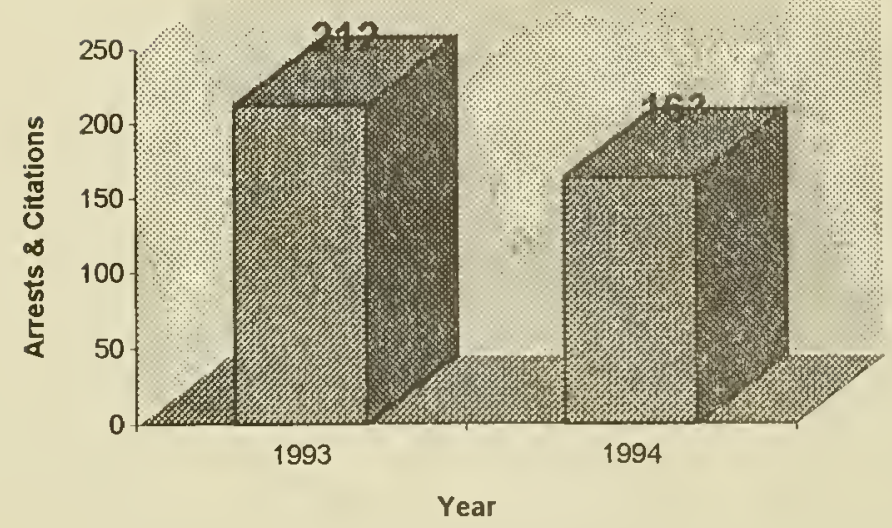

Figure 1.1 Decrease in arrests and citations in basin-wide special emphasis patrols during 1993 and 1994 salmon spawning migrations.

The results of the 1993 and 1994 special emphasis patrols show a decreasing trend in illegal activity ( Figure 1.1). The Special Emphasis Patrol in 1993 was called "Operation Corliss". CBLEC agencies joined forces to follow migrating sockeye and summer chinook all the way from the ocean to their spawning grounds in Idaho. This operation was implemented though the CBSET process. Agencies used WDFW's ocean-going vessel "Corliss" as a floating command/communications center. Corliss paced the salmon as they made their way through the Columbia Basin. Large contingencies of patrol officers operated both fore and aft of the Corliss. Ridged-hulled, inflatable Zodiacs were used by fisheries patrol officers to launch boat patrols from the decks of the Corliss. This was a 24 hours per day, seven days per week operation until the fish reached Lewiston. Not being able to navigate the Corliss any further, the operation continued to follow the fish. This time, jet-boats, horses, foot and aircraft patrols were used to follow the runs. This entire operation was highly publicized prior to initial implementation. A press conference was held in Vancouver, Washington when the Corliss reached that point in the patrol. In spite of significant advance publicity throughout the basin, 212 arrests were made during the operation. It should be noted that this operation was in addition to routine patrols by area officers. Arrest statistics calculated are associated directly with Operation Corliss and not every arrest made throughout the basin during the operation's time frame is included. Then in 1994, CBLEC did the same type of operation, except this time, it was low-profile and no publicity was disseminated. The 1994 patrol utilized about the same amount of personnel hours and occurred during the same time frame as Operation Corliss. Theoretically, this 1994 patrol should have resulted in more arrests than in 1993 because potential violators were unaware of the 1994 emphasis. Agencies were pleasantly surprised when in fact the 1994 patrol resulted in only 157 arrests, a $23 \%$ decrease from Operation Corliss the year before.

As depicted in the trends of effort and arrests graph (Figure 1.2) -- illegal activity is decreasing, in spite of the fact that effort has continually and significantly increased from the Pre-BPA period 
(1990-1991), through the demonstration period (1992-1994). Arrests initially increased in 1992 (the first year of the BPA Enhanced Enforcement Program) and then began to drop off significantly in 1993 and 1994. We draw the same conclusion from these data from Zone 6 -- as in the basin-wide results illustrated in the Special Emphasis Patrols graph (Figure 1.1) -deterrence is working!

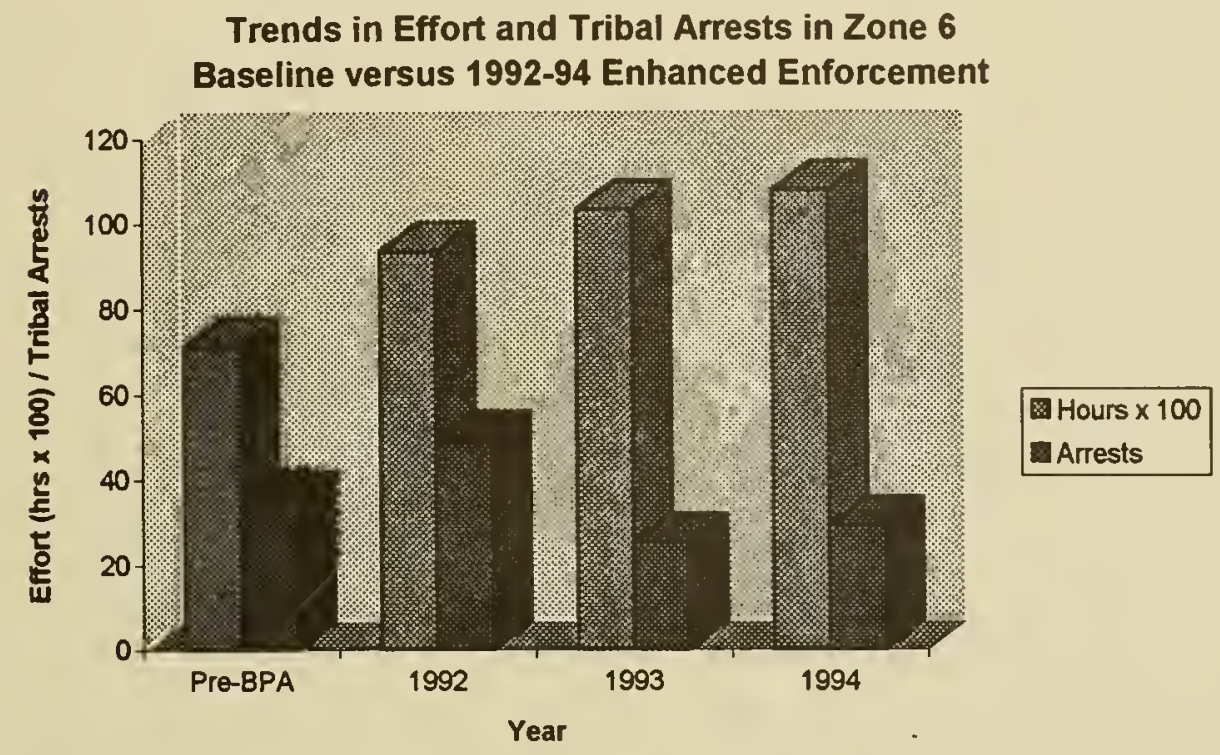

Figure 1.2 Trends in effort (patrol hours) and tribal arrests in Zone 6 during the 1990 baseline compared to the 1992-94 enhanced law enforcement demonstration period.

When CBLEC made a presentation for BPA's Fish and Wildlife Division, graphs were presented depicting Zone 6 statistical data. The data at that time depicted trends that would support an argument that the increased enforcement and public education was indeed having a deterrent effect on poaching. Dr. Pete Klingeman approached Steven Vigg of BPA (the enforcement program's technical representative) and asked him if the deterrent effect trends occurring in Zone 6 were present in other geographic areas throughout the basin. Data from throughout the Columbia Basin was subsequently collected and analyzed. The trends were the same.

Enforcement statistics increased significantly in 1992 (the first year of BPA funding) and then decreased thereafter. There was one exception in the basin and that was in the area below the Snake River at its confluence with the Columbia (Area 1K). In that particular area, arrests increased dramatically in 1992 and then continued to increase in 1993 and 1994. Historically, prior to the BPA funding, enforcement presence in Area $1 \mathrm{~K}$ was almost non-existent because of lack of personnel. Because of this lack of enforcement presence, and consequently lack of enforcement inter-action with the public in that area, it is expected that it may take longer for this area to fall into line with the deterrent effect trends of the rest of the basin which has historically had a constant enforcement presence, albeit inadequate. 


\subsection{Public Education and Awareness}

The public education and awareness component of the BPA Enhanced Enforcement Program is designed to provide the public with an objective perspective of the problems caused by illegal fishing activities and habitat degradation. When the public is made aware of the problems and consequences of unlawful activities, the program receives support from the majority.

Subsequently, when the "would-be" violator realizes that their intended unlawful activities are admonished by the majority and that there is an effective tool in place to deal with their unlawful actions, deterrence becomes even more effective.

Realizing the critical importance of public education, CRITFE assigned their Investigator direct responsibilities in this area. As mentioned previously in this report, the CRITFE Investigator, as an aspect of that position's job description, is assigned specific responsibilities relative to public education and awareness. The CRITFE Investigator coordinates public education with both the CBLEC Education Director (Rod Nichols) and Columbia River Inter-Tribal Fish Commission's Public Information Department. As a result of Rod Nichol's efforts, CRITFE and all CBLEC agencies have received media attention and public recognition locally, regionally and nationally. CRITFE has taken advantage of every opportunity to educate the general public, both Indian and non-Indian in the area of conservation enforcement. Deterrence can best be accomplished through public awareness of the increased law enforcement effort and the provision of mechanisms that allow the public to participate in the process.

\subsection{Evaluation Plan}

Ultimately, the success of the BPA funded law enforcement program will be measured by two factors (1) the increased public awareness of the importance of conservation of depleted Columbia and Snake River salmon stocks and the negative impact that illegal harvest and habitat degradation has on these stocks and (2) significant decreases in the actual take of anadromous salmonids and other depressed fish species throughout the basin.

An independent "third-party" scientific evaluation of the BPA funded law enforcement program should be initiated as soon as funds can be made available to provide for a detailed, holistic assessment of the efficacy of the program. This evaluation would best serve the participating agencies (CBLEC agencies and BPA) and more importantly, the resource, if it were designed in two components (1) an initial evaluation of the program up-to-date, assessing overall program efficacy and identifying needed changes and (2) an on-going assessment of the program based on necessary improvements as determined by the initial evaluation. As this report is being written, CBLEC agencies are in the "draft" stage of developing a long-term strategic enforcement plan. The short-term evaluation should include an analysis of the law enforcement statistics, fishery statistics, adult salmon dam passage and spawning escapement data, and measures of public opinion and help shape the specifics of long-term planning. The on-going evaluation should assess program efficacy based on goals and objectives of the long-term strategic enforcement plan. 


\subsection{Adaptive Management and Program Direction}

As new scientific and biological data are developed resulting in new hypotheses and restorative applications relative to rebuilding the salmonid resource in the Columbia Basin, enforcement must posture itself to be able to adapt to these dynamic processes and applications. There's a likelihood that more stocks will be listed under the Endangered Species Act, necessitating even a more aggressive role on the part of conservation enforcement. As mentioned, the CBLEC agencies in partnership with the BPA need to develop a long-term strategic enforcement plan. While the National Marine Fisheries Service, Enforcement Division, clearly, has mandated enforcement responsibilities under the ESA relative to anadromous fish, their philosophy has been and continues to be that the actual implementation of enforcement should occur at the local level (i.e., states and tribes) with federal agencies serving in a supportive role. This has worked well in the past and should continue to work well in the future but this supportive role needs to be expanded. To facilitate the expansion of NMFS' supportive role, BPA funding should be forwarded to NMFS in the form of a block grant. NMFS should then facilitate administration of the individual contracts with the states and tribes using budgets established during the 3-year demonstration period. There should be no overhead charges associated with NMFS's administration of this block funding (refer to CBLEC 5-Year Strategic Plan). Additionally, in support of the states and tribes, NMFS should enhance the data base already on line at the NMFS office in Astoria. A data base should be established so all participating CBLEC agencies can input statistical data directly into the system. The data base developed would of course require consistency of what types of data were processed into the data base. NMFS would be responsible for collection and analysis of this data in conjunction with the CBLEC 5-Year Strategic Plan. This should be done in such a way as to be able to develop statistical reports that are capable of demonstrating whether or not long-term enforcement goals and objectives are being accomplished. CBLEC agencies should be tied together electronically, not only for the purpose of collecting regional enforcement data, but also administratively via a multi-agency (CBLEC agencies) computer network so direct electronic communications can take place (E-mail, document transfer, etc.).

Because the CBLEC initiated BPA enforcement plan is on the basis of gravel-to-gravel management, it is essential to the success of effective basin-wide enforcement that individual tribes be factored into the process relative to tributary enforcement, both on-reservation and in ceded areas. Presently, many tribes that clearly have legitimate concerns and resources at stake, in the area of conservation enforcement relative to the ESA, do not have the enforcement resources to meaningfully and effectively participate in a basin-wide law enforcement program. As a federal agency, the National Marine Fisheries Service has certain trust responsibilities to treaty tribes involved in the protection of listed stocks. NMFS needs to play a major role, including providing financial assistance to individual tribes so they can be incorporated into the basin-wide conservation protection program and actively participate in the Columbia Basin Law Enforcement Council's enforcement planning and implementation processes. As this report is being written, NMFS has "stepped up to the plate" on this very issue and is working directly with affected tribes in assessing enforcement needs relative to the role they may play in long-term protection of depleted stocks throughout the Columbia and Snake River basins. Once this has been achieved, enforcement protections will exist throughout the geographic range of the resources we are all trying to preserve and protect. 

Chapter 2. Oregon Department of State Police-- Project 92-024-02

\author{
Captain Lindsay A. Ball, Division Director \\ Lieutenant Roger L. Tuers, Contact Person
}

\author{
Fish and Wildlife Division \\ Oregon Department of State Police \\ 400 Public Service Building \\ Salem, Oregon 97310 \\ phone (503) 378-3720
}

\title{
2.1 Introduction
}

The goal of the Oregon State Police for this Bonneville Power Administration project is to reduce the unlawful take of Columbia River Basin salmonids and native resident fish. This project is to provide enhanced protection of salmonids and native resident fish through increased law enforcement presence on the main-stem Columbia River and its tributaries, and thereby help to restore all endemic fish populations within the basin. Included within the definition of "unlawful take" is the unlawful harvest of adults and juveniles, harassment of spawners attending redds, destruction of eggs or fry within redds, direct mortality of juveniles caused by various human activities (like water diversions), and degradation of critical habitat. This project provides increased levels of enforcement to insure "gravel to gravel" protection of salmonids within the basin. The immediate goal is to insure that increased numbers of adult salmonids return to the spawning grounds. Longer team goals include habitat protection and downstream smolt protection. This project is an integral part of the Columbia River Fisheries Management Plan and directly addressed the goals and objectives identified by the Northwest Power Planning Council in rebuilding Endangered Species Act listed species.

\section{Rationale for BPA Enhanced Law Enforcement Program}

The geographical scope of the BPA-funded program is the entire Columbia River Basin including near shore ocean, estuary, mainstem, and tributaries. With the cooperation and support of the National Marine Fisheries Service and the U. S. Coast Guard, the geographic scope of enhanced law enforcement extends from the near shore ocean to the high seas. The targeted fish stocks are depleted anadromous salmonids and resident fish species, especially species petitioned or listed under the ESA. It is expected that enhanced protection will also extend to all other endemic fish populations in the Columbia Basin, which would include steelhead and white sturgeon. If the effectiveness of the enhanced law enforcement is demonstrated in terms of measurable results, BPA and participating CBLEC members partners in salmon enhancement will seek long term federal funding for increased levels of Columbia Basin law enforcement. The intent of federal funding is to provide an added level of effort over the baseline which the CBLEC entities are responsible. 
The states will provide the necessary law enforcement on the main stem and its tributaries. Included will be habitat protection, habitat restoration (by offending entities), and water diversion site conformance.

\section{Role of Law Enforcement in Columbia Basin Fish Restoration}

In this project the Oregon State Police has been provided seven (7) additional fish and wildlife enforcement personnel within the project area. It will provide for increased effectiveness of personnel through the acquisition of specialized equipment i.e., boating, surveillance, and aircraft. Agreed upon additions to this project have extended the scope of enforcement protection into salmonid habitat protection (spawning areas), and inventory of water withdrawal sites within the basin to provide increased protection to downstream migrating salmon smolt.

\section{Jurisdiction, Statutory Authority, and Inter-Agency Cooperation}

In the lower river below Bonneville Dam, OSP, and WDFW share the primary law enforcement responsibilities. The mid-Columbia aréa (Bonneville Dam to McNary Dam) have shared enforcement responsibilities with OSP, WDFW, and CRITFE. Oregon and Washington share the mid Snake River mainstem segment that comprised the primary spawning ground for Snake River fall chinook salmon. Oregon Revised Statutes place enforcement authority with the Department of State Police for Fish and Wildlife violations. This includes commercial fishery enforcement powers. CRITFE has enforcement authority over the four (4) Native American Tribes which have fishing rights on the Columbia River. OSP has signed agreements with two tribes for referrals on law enforcement violations. The two other tribes are treated equally as if there were signed agreements. If the respective tribal courts fail or decline to prosecute for alleged violations, the respective Oregon district attorney may prosecute. Oregon Revised Statutes compel prosecution for violations of the fish and wildlife laws, including commercial fishing violations. Coordination of effort among State, CRITFE, and Federal agencies participating in this project is accomplished through the Columbia Basin Law Enforcement Council (CBLEC). The CBLEC is an ad hoc council comprised of a representative of resource enforcement agencies within the Columbia River Basin from Oregon, Washington, Idaho, Montana, CRITFC, NMFS, and USFWS. This council was formally established in January of 1978 and to date, has provided for coordinated enforcement within the Columbia River Basin. Increased levels of public awareness is accomplished through the use of two public information officers employed by Idaho Department of Fish \& Game who coordinate efforts with project participants. 


\subsection{Enhancements during Demonstration Period versus 1991 Baseline}

The quarterly and annual expenditures of the Oregon component of the BPA enhanced law enforcement program are summarized in Table 2.1. BPA-funded positions (Full Time Equivalents, FTE) are summarized by month and year in Table 2.2. The eight OSP officers funded by the BPA grant were located at field stations throughout the Columbia Basin during 1994 (Table 2.3).

Table 2. 1. BPA budget for Oregon State Police, 1992-1994.

\begin{tabular}{|l|r|r|r|}
\hline \multicolumn{1}{|c|}{ Quarter } & \multicolumn{1}{c|}{1992} & \multicolumn{1}{c|}{1993} & \multicolumn{1}{c|}{1994} \\
\hline January-March & $95,048.78$ & $175,974.67$ & $151,138.85$ \\
\hline April-June & $274,838.17$ & $147,922.00$ & $184,861.42$ \\
\hline July-August & $310,498.53$ & $134,791.23$ & $176,659.88$ \\
\hline September-December & $205,589.73$ & $215,382.90$ & $254,708.28$ \\
\hline Annual Total & $\$ 907,947.03$ & $\$ 674,070.80$ & $\$ 767,368.43$ \\
\hline
\end{tabular}


Table 2.2. Additional BPA-funded law enforcement over 1991 baseline in the Columbia Basin, by month 1992-1994.

\begin{tabular}{|l|l|l|l|}
\hline Month & $\mathbf{1 9 9 2}$ & $\mathbf{1 9 9 3}$ & $\mathbf{1 9 9 4}$ \\
\hline January & $\mathbf{0}$ & $\begin{array}{l}\mathbf{7 . 0} \\
(\$ 27,260)\end{array}$ & $\begin{array}{l}\mathbf{7 . 0} \\
(\$ 33,019)\end{array}$ \\
\hline February & $\mathbf{0}$ & $\begin{array}{l}\mathbf{7 . 0} \\
(\$ 29,451)\end{array}$ & $\begin{array}{l}\mathbf{6 . 0} \\
(\$ 30,977)\end{array}$ \\
\hline March & $\begin{array}{l}\mathbf{5 . 0} \\
(\$ 22,533)\end{array}$ & $\begin{array}{l}\mathbf{7 . 0} \\
(\$ 28,699)\end{array}$ & $\begin{array}{l}\mathbf{7 . 0} \\
(\$ 37,957)\end{array}$ \\
\hline April & $\mathbf{7 . 0}$ & $\mathbf{7 . 0}$ & $\mathbf{6 . 5}$ \\
& $(\$ 28,824)$ & $(\$ 29,123)$ & $(\$ 32,190)$ \\
\hline May & $\mathbf{7 . 0}$ & $\mathbf{7 . 0}$ & $\mathbf{7 . 0}$ \\
& $(28,379)$ & $(\$ 29,946)$ & $(\$ 36,664)$ \\
\hline June & $\mathbf{7 . 0}$ & $\mathbf{7 . 0}$ & $\mathbf{6 . 5}$ \\
& $(\$ 27,876)$ & $(\$ 30,402)$ & $(\$ 31,809)$ \\
\hline July & $\mathbf{7 . 0}$ & $\mathbf{7 . 0}$ & $\mathbf{6 . 5}$ \\
& $(\$ 28,668)$ & $(\$ 30,124)$ & $(\$ 32,337)$ \\
\hline August & $\mathbf{7 . 0}$ & $\mathbf{7 . 0}$ & $\mathbf{6 . 0}$ \\
& $(\$ 27,056)$ & $(\$ 9,099)$ & $(\$ 30,234)$ \\
\hline September & $\mathbf{7 . 0}$ & $\mathbf{7 . 0}$ & $\mathbf{7 . 0}$ \\
& $(\$ 29,898)$ & $(\$ 30,098)$ & $(\$ 31,909)$ \\
\hline October & $\mathbf{7 . 0}$ & $\mathbf{5 . 0}$ & $\mathbf{6 . 0}$ \\
& $(\$ 27,835)$ & $(\$ 24,886)$ & $(\$ 30,692)$ \\
\hline November & $\mathbf{7 . 0}$ & $\mathbf{7 . 0}$ & $\mathbf{7 . 0}$ \\
& $(\$ 27,070)$ & $(\$ 29,864)$ & $(\$ 31,856)$ \\
\hline December & $\mathbf{7 . 0}$ & $\mathbf{7 . 0}$ & $\mathbf{7 . 0}$ \\
& $(\$ 27,117)$ & $(\$ 28,817)$ & $(\$ 31,825)$ \\
\hline
\end{tabular}

Table 2.3. OSP law enforcement officers funded by the BPA grant, 1992-1994.

\begin{tabular}{|ll|}
\hline Astoria & Michael J. Schacher, Senior Trooper \\
Scappose & Douglas F. Carter, Trooper \\
Portland & Gordon T. Landon, Senior Trooper \\
Portland (Investigations) & Rick L. Pert, Senior Trooper \\
Umatilla & Dennis A. Wagner, Trooper \\
La Grande & Robert N. Lund, Senior Trooper \\
Enterprise & Kevin (Tim) P, Johnson, Senior Trooper \\
\hline
\end{tabular}

Facilities, Communications, and Equipment 
Facilities for the Oregon State Police BPA positions are currently being housed by the Oregon State Police. One exception would be the Scappose Office of the OSP. During the pre-award period 1991 through 1993, this position was in Columbia City. However, due to OSP budget constraints, the Columbia City Office was moved to Scappose, Oregon.

During 1991, 1992, and 1993 BPA funding grant allowed OSP to purchase portable King radios. During 1994, a more sophisticated radio, namely Motorola Sabre portable radios were purchased. The sabre radio is capable of being encrypted which allows for private radio traffic. This has been a great improvement especially during covert operations. Many of success stories are due to the sophisticated equipment purchased allowed by the BPA funding grant. A list of non-expendable equipment purchased are available in inventory reports submitted to BPA.

\section{Inter-Agency Task Forces}

Virtually all non-expendable property, purchased by the BPA grant, has been used during our inter-agency task forces. The largest task force was completed in 1992 involving WDFW's patrol vessel Corliss. This was a highly visible operation which began at the mouth of the Columbia River and continued through the Snake River. It's design was to follow the endangered runs of salmon. Mainly overt operations were worked around the Corliss, but there were also covert operations as the vessel traveled up river. It was a highly successful operation. The off-shoot of this operation has continued each season during 1993 and 1994. The title given this has been the "Summer Emphasis Patrol". The success of this huge operation has shown that participating CBLEC agencies can coordinate and operate though out the Columbia Basin. This plan was developed through the Columbia Basin Law Enforcement Council (CBLEC).

The National Marine Fisheries Service coordinated this effort with participting CBLEC agencies. The Oregon State Police developed action plans from the mouth of the Columbia River to McNary Dam. Additional action plans were developed for the Snake River. Each action plan was followed up by a critique. The critique has allowed for adjustments and improvements for the following years. Accountability can be shown by these action plans and critiques, which also has contributed to the success of these operations.

\subsection{Current Methods for Enforcement Data Collection and Management}

\section{Field Data Collection}

Appendix 4 depicts the Columbia River Individual Activity Report. This report is done on a monthly basis. Every officer who works the Columbia Basin will fill out this report and record his/her individual statistics which apply to the form. The Oregon State Police form is divided into two sections. One for recording information devised by CBLEC, and the second section for OSP information only. On the back of the form, the mainstem Columbia River is divided into specific areas. The officer will mark the area in which he/she worked, the amount of time spent in that area, whether his/her patrol hours were spent on commercial, sport ceremonial, or aircraft hours. 
Also recorded is time spent working with another agency, or other participating CBLEC agencies. Investigative and environmental time is also recorded plus amount of salmon, steelhead or sturgeon seized. The amount of commercial and sport arrests and whether any nets or other gear was seized. The final category is the amount of enforcement contacts.

The OSP section asks for boat hours patrolled, number of warnings for commercial and sport violations, overtime hours worked, commercial, sport, and environmental complaints handled, and amount of vehicle miles travelled per day.

\section{Data Management System}

In Oregon, the Columbia River Individual Activity Reports are compiled monthly and checked by the area Sergeant. Each Sergeant will forward these monthly reports to OSP General Headquarters in Salem and to the National Marine Fisheries Office in Astoria, Oregon. At the OSP Headquarters in Salem, the daily activities are compiled and verified into a state wide total. Each yearly quarter, January, April, July, and November these figures are released to BPA and NMFS with a compliance index. OSP computes the compliance index as the number of contacts versus the number of arrests and warnings.

Similarly, the National Marine Fisheries Service in Astoria, Oregon receives reports from the other participating CBLEC agencies. This information is verified and computerized for the entire Columbia Basin project. (See the NMFS report as to categorizing statistics).

\section{Data Analysis}

With the above listed data, measurements can be recorded per area of work for individual areas i.e. unit 1,2,3 etc., or areas 1A, 1B, $1 \mathrm{C}$ etc. Computations can be divided into Columbia River Zones, 1 through 6. Oregon can also compute statistical information for the Snake River and Oregon tributaries of both the Columbia and Snake rivers. Compliance rates can be achieved per river or tributary. These compliance rates can be compared with out of state tributaries. Knowledge gained by using the statistics will cause focus of enforcement toward lower compliance areas.

In 1986 Oregon began writing Action Plans. The Plan identified a problem, historical information about the problem was written as observed by enforcement officers. Biologists were contacted regarding historical information they had compiled. An Objective was determined, the Method of Operation was formulated, the Duration of the plan was determined, and the amount of personnel and equipment needed to complete the plan. After the plan was completed an "After Action Plan Critique" was written.

As a result and success of Action Plans, Cooperative Enforcement Plan (CEP) was initiated. This brought Oregon State Police, Fish \& Wildlife enforcement officers together with Oregon Department of Fish \& Wildlife biologists. Yearly both forces meet and determine, for the entire year, on a month-by-month basis what issues are a high, medium, and low priority. After the 
priorities are set an individual enforcement officer can determine what area needs special efforts and an Action Plan is developed.

These methodologies has been encompassed into Oregon's Benchmarks, namely Quality of Life. Two examples of these Performance Measures can be illustrated in measures of License Compliance Rates and Anadromous Fish Protection: Information gathered on license compliance rates indicates that for each one percent $(1 \%)$ increase in compliance rate, the licensing revenues to ODFW increases approximately $\$ 230,000$ per year. The analysis also determined that reduced enforcement presence in the field would result in a lower compliance rate.

Increased compliance will generate increase protection of threatened or endangered species.

Strategies include education, collaborative planning, partnerships and enforcement. Success of the enforcement effort will be evaluated by fisheries biologists with respect to voluntary compliance complementing their management goals and objectives. If the achieved compliance level compliments the management goals and objectives, then enforcement efforts are effective.

\subsection{Results}

Table 2.3. Enforcement Statistics in Oregon, 1992-1994.

\begin{tabular}{|l|l|l|l|}
\hline Statistic & 1992 & 1993 & 1994 \\
\hline Arrests & 1019 & 515 & 447 \\
\hline Commercial & 74 & 38 & 3 \\
\hline Sport & 945 & 477 & 444 \\
\hline Warnings & 1557 & 911 & 602 \\
\hline Commercial & 93 & 37 & 21 \\
\hline Sport & 1464 & 874 & 581 \\
\hline Officer months & 108.3 & 107.4 & 119.67 \\
\hline Enforcement field hours & 18,772 & 18,616 & 20,742 \\
\hline Number of patrols: & 2372 & 2407 & 2412 \\
\hline Contacts & 11,955 & 8,584 & 10,026 \\
\hline Compliance rate & $78.5 \%$ & $83.4 \%$ & $89.5 \%$ \\
\hline
\end{tabular}


Table 2.4. Comparison of BPA-funded effort versus state funded effort in Oregon, 1994.

\begin{tabular}{|l|l|l|l}
\hline STATISTIC & $\begin{array}{l}\text { BPA FUNDED } \\
\text { EFFORT }\end{array}$ & $\begin{array}{l}\text { STATE FUNDED } \\
\text { EFFORT }\end{array}$ & $\begin{array}{l}\text { COMBINED } \\
\text { EFFORT }\end{array}$ \\
\hline TOTAL ARRESTS & 163 & 284 & 447 \\
\hline COMMERCIAL ARRESTS & 2 & 1 & 3 \\
\hline SPORT ARRESTS & 161 & 283 & 444 \\
\hline TOTAL WARNINGS & 208 & 394 & 602 \\
\hline COMMERCIAL WARNINGS & 7 & 14 & 21 \\
\hline SPORT WARNINGS & 201 & 380 & 581 \\
\hline
\end{tabular}

Forward Looking InfraRed Imaging System (FLIR)

In March of 1992, the Oregon State Police purchased a Forward Looking infrared imaging system (FLIR) through the BPA-funded grant. The FLIR has probably been the most pronounced deterrent along the Columbia and Snake rivers. Commercial arrests have dramatically decreased due to enforcement efforts and media exposure associated with the FLIR. It is not uncommon for enforcement officers in the Columbia Basin to receive remarks such as, "Hey, you guys were up again last night, what are you looking for now?" With this type of exposure, any airplane which flies in the basin is suspected of carrying the FLIR.

The FLIR is mounted on the OSP Cessna 185 airplane and has flown 271.5 hours from March 1992 to December of 1994 . This represents over 84 flights when the FLIR has been used in the basin. These figures include inter-agency work.

In addition to its use in the basin, the FLIR has been instrumental in locating unlawful dumping of chemical wastes from toilets, indoor marijuana grow operations, 2 murder suspects, and spotlighters. The primary use has been in the basin; however, occasionally additional requests have been made for it use. The FLIR can be easily unmounted when the OSP plane is requested for other purposes.

\section{Pump Station Survey}

Survey of fish protective facilities at water withdrawals on the Snake and Columbia rivers was undertaken by BPA in fiscal year 1979. In 1980 BPA financed the inspection study and found 205 pump stations located between Bonneville Dam and Wells Dam on the Columbia River and at the confluence of the Lewiston on the Snake River. At that time only 77 of these sites had Corps permits. This study found that $65 \%$ of the pump station inspected were not in compliance with the screening requirements.

In the summer of 1992, a fish kill occurred at a single pump station on the Umatilla River approximately $1 / 4$ mile upstream from the Columbia River. This kill destroyed an estimated 46,000 fall chinook smolt. The case was investigated by the Oregon State Police, Fish \& Wildlife 
Division. The pump station manager was issued a citation for "Tampering with a Fish Screening Device", and terminated from the employment of the Irrigation District.

Based on this incident and previous surveys conducted by the Oregon Department of Fish \& Wildlife, U. S. Fish \& Wildlife Service, and Bonneville Power Administration, a private contractor was hired to conducted a survey of this area. The proposal outlined a three phase plan: 1) Locate and inventory all pumps on the Columbia River between Bonneville Dam and Wells Dam and on the Snake River from its confluence to the Grande Rhonde River, upstream from Lewiston, Idaho, a total distance of 525 miles; 2) Conduct underwater inspections of fish screening devices at all withdrawal sites within the scope of this survey. This inspection is to be done during the irrigation season. The results would be forwarded to BPA or a designated Law Enforcement Agency on a daily or weekly basis; and 3) Specific follow-up inspection as required by BPA or a designated agency.

Work on this phase started on January 6, 1993 and was completed March 13, 1993. It involved 20 working days. Delays occurred due to wind, fog, ice and subzero temperatures. A total of 3460 road miles were driven and 1000 miles covered by boat. Seven hundred nine (709) pumps were located in the inventory which was an increase of over $300 \%$ since the 1980 survey.

In March of 1995, the Oregon State Police will award a contract to follow up on Phase III of the initial contract. This will include revisiting all the pump stations, measuring velocity, inspecting screens, and photographing the sites. Additional work by the Oregon State Police, Fish \& Wildlife Division is in Phase 1 at the present time, identifying water withdrawal sites below Bonneville Dam, including dredging operations. Future plans will include locating withdrawal sites on the Columbia and Snake river's tributaries within Oregon.

\section{Habitat Work}

Oregon has been mandated by its legislature to improve the "Quality of Life" as identified by one of its Benchmarks. This includes water quality, not just for fish habitat but for overall human enjoyment for years to come. The complexity of habitat issues include, the Forest Practice Act of Oregon, Fill and Removal regulations, riparian work with and coordinated by the Department of Fish and Wildlife, and mining operations just to name a few.

When Oregon contacted with BPA in the Fall of 1991, five (5) positions were identified for fisheries work. Almost immediately a sixth position was requested for habitat work. Although Oregon has been involved with habitat work in the past, the BPA contract grant has enabled the Oregon State Police to fund one position at $100 \%$ for habitat enhancements. Senior Trooper Bob Lund, La Grande, has done extensive work on the Grande Rhonde with fill and removal action plans in Union, Baker, and Wallowa counties. These areas include the headwaters of the Grande Rhonde to State line, Granite/North Fork of the John Day, Catherine Creek, Lookingglass, Sheep, 5 Point, Phillips, Minam, Wallowa-Rondowa to Lostine. 
These efforts increased the Fish \& Wildlife Division's partnership with the state's Water Masters, the Division of State Lands, and the Department of Environmental Quality. The long-range goals for habitat work will reach all the major Columbia River tributaries in Oregon.

\section{Public Education and Awareness}

All public education and awareness is coordinated through the Columbia Basin Law Enforcement Council (CBLEC). Additionally, as a result of two Oregon State Police programs, namely Cooperative Enforcement Planning (CEP) and Service Orientated Policing (SOP), a trial project has been initiated. This includes members of the public being invited to join in the CEP process. This gives the public a first-hand account of how the State Police prioritized activities, plus allowing the public to be part of the process by their input toward problem solving and setting prionities.

The public continues to be invited to all Oregon Department of Fish and Wildlife Commission meetings. The commission has endeavored to move meeting locations around the state to allow for more discussions and reaching out to a more diverse group. The Columbia River Compact also allows public testimony; date, time, and location are always published to advise and encourage public input.

The public awareness component of the increased law enforcement grant is designed to provide a balanced perspective of problems caused by unlawful fishing and habitat degradation, and the opportunities associated with increasing the survival of adult spawners returning through the mainstem Columbia to their natural spawning grounds. Unlawful take by all segments of harvesters must be reduced in both the ocean and river, sport and commercial which includes inadvertent harvest by anglers ignorant of fish identifications or the laws.

The majority of commercial, tribal, and sport harvesters voluntarily comply with regulations that they are aware of, understand, and support. Public appreciation of the anadromous fishery resource, and the knowledge of laws intended to protect it is potentially the best enforcement tool to guide actions of fishers, and reporting of criminal activities by the general public. The Oregon State Police will continue to use its portable exhibits at fairs, sport shows, mall exhibits and professional meetings in an attempt to keep the public informed.

Oregon State Police Fish \& Wildlife's top program in public education is Turn In a Poacher (TIP). This program has a 1-800 number in all Fish \& Wildlife's publications. All anglers whether sport or commercial, and all hunters who have read their regulations can find this number. They are encouraged to report all violations. Awareness of various Fish \& Wildlife programs can also be heard in different parts of Oregon through 60 second radio accounts. Through a cooperative effort with the Oregon Department of Transportation, the Oregon State Police have established radio recorded messages for different fish and game management areas or subareas. As a motorist drives by a particular location, signs indicate a radio channel to access information regarding areas of fish and wildlife interest. 


\subsection{Evaluation Plan}

Improvements in data collection and analysis

As discussed earlier, the Columbia Basin Law Enforcement Council (CBLEC) is the quorum in which all participating agencies gather to assimilate information. In order to improve data collection and analysis, it is very important that each agency in the program collect comprehensive data in a consistent and coordinated manner, which in turn will facilitate subsequent analysis of the entire program. Presently, quarterly reports are being prepared and forwarded to BPA so it can monitor progress. Then a yearly report is submitted. This data can then be analyzed and BPA may interpret the effectiveness of the entire program.

\section{Measurement of Enforcement Effectiveness}

Specific criteria to judge the success of this program will include: (1) publicity, through various media, on the size and extent of the program -- currently there are two public relation officers assigned to CBLEC ; (2) awareness of the public that law enforcement is greatly increased on Columbia and Snake river salmon runs; (3) overt presence measured by increased numbers of uniformed officers in the field and total time spent on patrol; (4) increased utilization of sophisticated communications and surveillance capabilities of the law enforcement force; (5) increased use of inter-agency coordination and saturation task forces where problems exist; (6) decreased market availability of unlawful salmon as measured by covert operations; (7) ability to estimate the extent of unlawful harvest of salmon and steelhead throughout the Basin; (8) decreased inter-dam loss that is attributable to decreased unlawful harvest; and (9) increased number of adults spawners escaping to spawning areas.

Enforcement statistics provide a measure of the success of a program -- based on trends of arrests, fish seized, and nets \& equipment seized. An increase in any one of these areas will show an enforcement officer that the unlawful taking is occurring and on the increase. Actually, when the data show a decrease in arrests and seizures, the program is working. This analysis is based on prior experience.

\section{Measurement of Biological Benefits}

One of several biological objectives is improvement in adult salmon survival during upstream migration through the Columbia and Snake rivers. Monitoring changes in previously unaccounted losses in migrating salmonid populations and analyzing inter-dam conversion rates provides a basis for quantitative evaluation. A longer term data base is needed to quantify the biological effectiveness of the enhanced law enforcement program. The three years in this demonstration period is not sufficient time. It may be an indicator, but more time is needed for a biological opinion.

Input to Recovery Plans and ESA Section 7 Consultations 
The Oregon legislature in taking a "hard look" at the meaning of "the best available scientific evidence" not just due to Judge Malcolm Marsh's decisions, but also on how ESA listings are determined, how to delist a species (Northern Spotted Owl), and should an ESA listing include the economic, social, cultural and human needs. Oregon is not trying to "re-invent the wheel", but simply stating that ESA listings have not been based on the best available scientific evidence, if you take into account economical and social needs.

Continuation of the BPA-funded enhanced law enforcement program past the three-year demonstration period is one alternative which can be measured. Results from the 1995 program can be evaluated and should be considered by the National Marine Fisheries Service in the additional analytical reports, and alternatives and measures as required in the Federal Columbia River Power System (FCRPS) Biological Opinions (Recovery Program Statistics).

\section{Independent Third Party Evaluation}

The efficacy of the ongoing enforcement program will be evaluated on a continuing basis to determine the subsequent course of action and if additional BPA funding or other federal funding is warranted. Currently it has been shown that a continuation of this program is essential. An independent scientific evaluation of the BPA-funded law enforcement program will be initiated in 1995. This should be a CBLEC function in which all involved agencies will have input to determine measurable criteria and biological objectives. These biological objectives should support the overall goal of rebuilding and recovery of depleted fish stocks in the Columbia Basin. Oregon's participation will be coupled with ODFW as to biological data.

\subsection{Adaptive Management and Future Project Improvements}

BPA and Oregon enforcement entities agree that ongoing program evaluation and adaptive management of the program is beneficial and necessary for long-term effectiveness. Oregon believes the best adaptive management tool to be used would be a third party evaluation of the overall enforcement program. Each agency should have this "third party" evaluate their program and if necessary make changes to eliminate ineffective components, reduce redundancies, and increase cost-effectiveness. However, this is another funding issue and must be supported by a separate funding source other than the agency's. It may be necessary for each agency to submit an additional line item for such an independent study in their respective budget with BPA.

Some potential adjustments and additions to the enhanced program are:

1. Develop a comprehensive Columbia Basin fishery and habitat enforcement strategic plan and seek a stable long-term funding base for implementation of that plan.

2. Take actions to improve the effectiveness of the Columbia Basin Law Enforcement Council without adding bureaucratic layers or significant costs to the program.

3. Actively seek cooperation and involvement of individual Columbia Basin Indian Tribes in the enhanced law enforcement program.

4. Look for improved methodologies for planning, implementing and evaluating inter-agency efforts and sharing of resources. 
5. Seek legislative and state fish and wildlife code changes that will improve effectiveness of law enforcement and fish protection.

6. Continue habitat protection efforts, provide enhanced training of officers in fishery habitat requirements and environmental crime, and strengthen coordination with regulatory agencies.

7. Continue with statistical methodologies and measures of effectiveness that are consistent among all participants such as the current compliance rate system.

8. Improve computerized data management systems by maintaining consistent methodologies in collecting and reporting data.

9. Increase the involvement with the USFWS National Fish \& Wildlife Forensics Laboratory in Ashland, Oregon by exploring possibilities of developing a DNA data base for identifying ESA listed fish.

Developing a long term strategic plan, 5 to 10 years, and re-analyzing the overall program for potential improvements may be the best way to implement adaptive management and future project improvements. 



\title{
Chapter 3. Washington Department of Fish and Wildlife -- Project 92-024-03
}

\author{
Chief Dayna Matthews, \\ Assistant Director \\ Washington Department of Fish and Wildlife \\ Enforcement Program \\ 600 Capitol Way North \\ Olympia, Washington 98501-1091
}

\subsection{Introduction}

The overall goal of the BPA-funded enforcement project is to provide for an enhanced enforcement protocol that will protect salmonid and other depleted fish stocks throughout the Columbia River basin. WDFW's emphasis is in the waters of the Snake River and the waters of the Columbia River downstream from the State of Idaho to the mouth of the Columbia River, and north along the coastal waters of the State of Washington.

The primary goal of this law enforcement effort is to provide for protection of returning adult salmon and increase the rate of survival of juvenile salmon through fisheries and habitat protection and enforcement, ultimately to rebuild depressed runs of Snake and Columbia River salmon stocks. Additional enforcement protection is also provided for resident fish that are listed under the Endangered Species Act.

\section{Objectives:}

1. Maintain enforcement officer presence and effectiveness.

2. Purchase and maintain equipment and facilities necessary for increased law enforcement and public awareness effort.

3. Maintain law enforcement efforts during anadromous salmonid runs throughout the mainstem, tributary, and lake spawning areas, and assist with cooperative inter-agency enforcement efforts throughout the Columbia River basin, from tributary streams to the mouth of the Columbia, and north along the Washington State coast.

4. Enhance coordination of enforcement efforts with other Columbia River basin enforcement agencies (USFWS, NMFS, IDFG, OSP, and CRITFE) through the Columbia Basin Law Enforcement Council (CBLEC) and other appropriate mechanisms; and with Native American tribes within the Columbia River basin.

5. Coordinate and conduct the increased public awareness project to educate the public throughout the region on the effects of illegal harvest on Columbia and Snake River basins' anadromous salmonid stocks, with emphasis on the need to conserve depleted stocks and the ecosystems upon which they depend. The public information must represent a balanced and comprehensive perspective on all issues related to conservation of anadromous salmonids throughout the Columbia River system. 
6. In an ongoing manner, evaluate the efficacy of the increased law enforcement and public awareness efforts in decreasing illegal harvests throughout the Columbia River basin.

7. Develop a strategy for long-term funding of the program, coordinated with the NMFS Recovery Plan, NPPC Fish and Wildlife Program, and the BPA.

The above stated enforcement goals can be achieved by creating an expectation of being caught for those who violate resource protection measures now in place. This objective can be further implemented by increasing the presence of uniformed officers, increasing efforts in covert and overt investigations, and through the use of sophisticated surveillance equipment in the Bonneville Power Administration core areas of concern, the Columbia River Zone 6, McNary Dam to the Tri-Cities, and the Snake River.

Adequate resident enforcement coverage accomplishes at least three tasks; first, it forces the poacher to either operate when there is an enforcement presence (risking capture), or forces the poacher to quit or move. Second, if the poacher moves, he or she is in unfamiliar territory, thereby increasing the chance of apprehension. Third, the resident officer living within the community becomes an intrinsic component of public education efforts designed to raise the awareness and conscience of resource protection and responsibility.

The Washington Department of Fish and Wildlife shares the responsibility of these enforcement goals and objectives with the Columbia River Inter-Tribal Fisheries Enforcement, Oregon State Police, and Idaho Fish and Game. The total annual BPA-budget for enhancement of Washington's Columbia Basin fishery enforcement effort averaged about $\$ 1.04$ million during 1992-1994 (Table 3.1).

Table 3.1 Quarterly expenditures for the Washington component of the BPA-funded salmon enforcement project

\begin{tabular}{|l|l|l|l|}
\hline \multicolumn{1}{|c|}{ Quarter } & \multicolumn{1}{c|}{1992} & \multicolumn{1}{c|}{1993} & \multicolumn{1}{c|}{1994} \\
\hline January-March & 256,637 & 392,506 & 133,259 \\
\hline April-June & 457,365 & 555,844 & 394,049 \\
\hline July-September & 251,628 & 318,415 & 100,153 \\
\hline October-December & 278,890 & 0.00 & 104,124 \\
\hline \multicolumn{1}{|c|}{ Annual Total: } & $\mathbf{\$ 1 , 2 4 4 , 5 2 1}$ & $\mathbf{\$ 1 , 2 6 6 , 7 6 4}$ & $\mathbf{\$ 7 3 1 , 5 8 4}$ \\
\hline
\end{tabular}

Statutory Authority

WDFW authority for enforcement is established under the Revised Code of Washington (RCW) 75.10 .010 and 77.12 .055 .

\subsection{Personnel}


The BPA-funded positions for enhancement of Washington's Columbia Basin fishery enforcement effort has been a maximum of 10.5 full-time equivalents (FTE) during 1992-1994 (Table 3.2).

Table 3.2 Number of Washington full-time equivalents (FTE's) over 1991 baseline, and corresponding monthly cost (salary and benefits) -- provided by BPA funding for Columbia Basin law enforcement enhancement, 1992-1994.

\begin{tabular}{|l|c|r|r|}
\hline Full-Time Equivalents and Cost: & \multicolumn{3}{|c|}{ Year } \\
\hline Month & \multicolumn{1}{|c|}{1992} & \multicolumn{1}{|c|}{1993} & 1994 \\
\hline January & 1.00 & 8.55 & 10.09 \\
& $(\$ 4,280)$ & $(\$ 36,594)$ & $(\$ 43,185)$ \\
\hline February & 1.59 & 10.57 & 8.95 \\
& $(\$ 6,805)$ & $(\$ 45,240)$ & $(\$ 38,306)$ \\
\hline March & 5.56 & 11.03 & 9.58 \\
& $(\$ 23,797)$ & $(\$ 47,208)$ & $(\$ 41,002)$ \\
\hline April & 5.06 & 10.76 & 9.49 \\
& $(\$ 21,657)$ & $(\$ 46,053)$ & $(\$ 40,617)$ \\
\hline May & 7.74 & 11.28 & 8.33 \\
& $(\$ 33,127)$ & $(\$ 48,278)$ & $(\$ 35,652)$ \\
\hline June & 11.45 & 14.37 & 9.82 \\
& $(\$ 49,006)$ & $(\$ 61,504)$ & $(\$ 42,030)$ \\
\hline July & 8.61 & 8.08 & 4.25 \\
& $(\$ 36,851)$ & $(\$ 34,582)$ & $(\$ 18,190)$ \\
\hline *August & 8.08 & 11.52 & 1.00 \\
& $(\$ 34,582)$ & $(\$ 49,306)$ & $(\$ 4,280)$ \\
\hline September & 11.48 & 7.72 & 7.99 \\
& $(\$ 49,134)$ & $(\$ 33,042)$ & $(\$ 34,197)$ \\
\hline October & 8.25 & 10.26 & 6.04 \\
& $(\$ 35,310)$ & $(\$ 43,913)$ & $(\$ 25,851)$ \\
\hline November & 7.02 & 7.55 & 1.09 \\
& $(\$ 30,046)$ & $(\$ 32,314)$ & $(\$ 4,665)$ \\
\hline December & 7.52 & 8.00 & 9.84 \\
& $(\$ 32,186)$ & $(\$ 34,240)$ & $(\$ 42,115)$ \\
\hline Average Annual FTE & 6.95 & 9.97 & 7.21 \\
\hline
\end{tabular}

* 8/94 drop in FTE due to no coastal or Buoy 10 recreational salmon fishery in 1994. 
Table 3.3. Current personnel assigned to the BPA-funded salmon enforcement project.

\begin{tabular}{|lll|}
\hline Name & Station & Position \\
James Brown & Clarkston & WDFW Officer \\
Gary Orr & Stevenson & WDFW Officer \\
Morgan Grant & Cathlamet & WDFW Officer \\
Mitch Messenger & Goldendale & WDFW Officer \\
VACANT & Dayton & WDFW Officer' \\
Robin Ayers & Olympia & Clerk Typist 3 \\
Charlotte Nicholas & Olympia & Fiscal Technician $(0.50)$ \\
Val Judkins & Olympia & Pilot/WDFW Officer \\
James McColgin & Franklin Co. & WDFW Sergeant \\
Charles Pudwill & Battleground & WDFW Investigator \\
Rey Reynolds & Battleground & WDFW Investigator \\
\hline
\end{tabular}

${ }^{1}$ Position to be filled by $5 / 1 / 95$.

\subsection{Screening Violations - Benton and Klickitat Counties}

The WDFW statewide Special Investigative Unit (SIU) was tasked with developing "appropriate action" against 45 screening violators in Benton and Klickitat Counties.

Non-compliance letters were sent out to 45 violators. Eight violators failed to respond to a second compliance letter. The Revised Code of Washington (RCW) 75.20 .040 requires that within 30 days of receiving notification that intake pumps are not up to State of Washington screening standards, a party must respond with a plan of action to correct the deficiencies.

Screening enforcement had three phases which proved useful and successful. These were case (1) integrity maintenance, (2) prosecutor support, and (3) enforcement contacts with violators prior to filing charges. The use of local newspapers was explored and will be fully implemented as Phase II of the inspection process gets underway.

\section{Case Integrity.}

As noted, it is unlawful to fail to respond to a Notice of Non-Compliance. The RCW states that for every day following the notification it becomes a crime, chargeable as a gross misdemeanor each day, per day of non-compliance. Coordinating carefully with all Department staff, all contacts with violators or any activity on or around the property must be via search warrant or written consent. All contacts with violators were documented in writing.

\section{Prosecutor Support}

The most important aspect of the program was to garner support from the local jurisdictions to actively prosecute any cases that we brought to their attention. This was accomplished by putting together presentations to the respective jurisdictions. The presentations included historical 
screening perspectives, summary of laws affecting the screening process, enforcement strategies, and search warrant planning. The presentations were well received by the prosecutors and support was immediately given for filing charges against violators who did not comply. This support took the form of:

\section{Klickitat County}

1. Prosecutor sending letter of intent to prosecute to violators;

2. Immediate assigning of Deputy to prosecute;

3. Support in seeking damages.

\section{Benton County}

1. Deputy prosecutor assigned to prosecute violators;

2. Support in seeking damages;

3. Access to prosecutor.

It should be noted that this type of support is unparalleled in other Eastern Washington counties.

\section{Enforcement Contacts}

Violators who failed to comply to a final letter were contacted either by letter or by telephone. The letter sent out by Klickitat County prosecutors contained information related to the prosecutor during the presentation. Phone contacts with violators in Benton County related the same information. Response was immediate and positive by all violators.

Future Screening Activities

Phase 2 of the screening program has begun. The SIU will be sending out press releases complimenting responsible Columbia River water users who have complied with screening regulations. This release will be followed up with an additional release warning would-be violators of the consequences of not complying. Future presentations to Grant, Yakima, Klickitat, and Chelan County prosecutors are being prepared and scheduled. WDFW is optimistic and anticipate similar results.

\subsection{Results}

The result of the screening activities has been $100 \%$ compliance. All violators have either complied or are actively participating in programs to bring screens into compliance. Cooperation between the WDFW Habitat and Enforcement Programs contributed significantly to direct protection of the salmon in the areas. The local prosecutors are pleased with the outcomes and have applauded the SIU for successful conclusion of these cases. 
Table 3.4. Enforcement statistics in Washington, 1992-1994.

\begin{tabular}{|l|r|r|r|}
\hline \multicolumn{1}{|c|}{ Category } & 1992 & 1993 & 1994 \\
\hline Total Area Hours & 9,956 & 12,028 & 7,856 \\
\hline Commercial Enforcement Hours & 2,584 & 2,836 & 941 \\
\hline Sport Enforcement Hours & 7,131 & 8,690 & 6,165 \\
\hline Ceremonial Hours & 241 & 502 & 293 \\
\hline Aircraft Hours & 370 & 461 & 35 \\
\hline Habitat Hours & -- & -- & 457 \\
\hline Interagency Hours & 2,747 & 3,277 & 782 \\
\hline Investigations (Hours) & 1,219 & 1,848 & 800 \\
\hline Salmon Seized & 62 & 29 & 12 \\
\hline Steelhead Seized & 95 & 19 & 40 \\
\hline Sturgeon Seized & 25 & 57 & 30 \\
\hline Commercial Arrests & 16 & 63 & 21 \\
\hline Sport Arrest & 698 & 1,057 & 759 \\
\hline Nets Seized & 1 & 28 & 3 \\
\hline Contacts & 14,653 & 18,270 & 13,886 \\
\hline Public Relations (Hours) & - & -- & 60 \\
\hline
\end{tabular}

\section{Special Investigative Unit (SIU)}

WDFW's Special Investigative Unit (SIU) conducts covert law enforcement activities, in cooperation with other CBLEC entities, throughout the Columbia Basin. Due to the need for confidentiality, details of current and ongoing operations are not reported here. The following bullets summarize sport and commercial fishery investigations during 1992-94.

- Multiple Washington, Oregon, and Alaskan Wholesale Fish Dealer Investigations Involving Oregon State Police and Intertribal Enforcement -- multiple convictions in Oregon and Washington courts.

- Multiple Joint Investigation with Inter-Tribal Enforcement and Oregon State Police on tribal members selling subsistence salmon from ESA areas -- multiple convictions in State and Tribal courts.

- Sale of sport caught salmon/sturgeon from lower Columbia River tributaries -- multiple convictions and ongoing investigations.

- Multiple investigations with Oregon State Police involving local immigrant communities commercializing sport-caught salmon and sturgeon on the lower Columbia -- multiple convictions and numerous ongoing investigations.

- Assist in multiple wholesale dealer and restaurant sales of salmon and steelhead in Oregon -multiple convictions and ongoing investigations. 
- Ongoing investigations involving taverns, groceries, restaurants, and individuals involving buying, selling, and trafficking in salmon, sturgeon, and other wildlife parts.

- Numerous unlicensed salmon/steelhead/sturgeon guide cases on the lower and middle Columbia and its tributaries and the upper Snake rivers. Many cases included support of and involvement with the Oregon State Police -- multiple convictions and ongoing investigations.

- Numerous unlicensed salmon/sturgeon guide cases on the lower Columbia River and the ocean. Many cases included support of and involvement with the Oregon State Police -- multiple convictions.

- Assist Alaska, California, Oregon, Idaho, and Montana on numerous investigations involving residency issues and involvement of Washington residents in cross jurisdictional fish/wildlife crimes.

Washington's SIU is also involved in environmental crime investigations; the following points summarize activities in this area.

\section{A. Fish Screening Investigations}

- Coordinated enforcement activities for the Columbia River. Working in tandem with biologist-utilized local media and county prosecutors to advise and inform water users of screening requirements. Following contact with over hundreds of users, only 10 required direct enforcement action. These then complied with requirements prior to prosecution.

B. Hydraulic Project Investigations

- Numerous ongoing cases involving the loss of habitat and destruction of shoreline on the Columbia River and its immediate tributaries. Some of these include bridge razing activities, bridge painting, river sand mining, grave mining, dumping into the River, hazardous waste containment. Most cases involved prosecution, resultant convictions required the defendant to repair/restore the site, remove unlawful dumped material, contain hazardous material, obtain required permits, and pay on the average of $\$ 2,000$ in fines.

C. Hydraulic Project Monitoring

- These activities are designed to monitor ongoing permitted activities to ensure compliance with written conditions. The activities include on site inspections, permit review, and meetings with habitat biologist on permitted activities. Work load includes approximately 5 monitoring activities per week. 


\section{Environmental Crimes}

- Currently developing framework for the investigation environmental crimes involving hazardous material affecting Threatened and Endangered species fish on the Columbia River and Snake River. These activities include establishing a data base of past and current violators of Hazardous Materials rules and laws.

\subsection{Evaluation of the Law Enforcement Program}

Achievement of success for this law enforcement program is defined as increased public awareness of the importance of conservation of depleted Columbia and Snake river salmon stocks, and recognition of the negative impact that illegal harvest has on depressing these weak stocks. Most importantly, the goal is to significantly decrease the illegal harvest of all anadromous salmonids throughout the basin. Public opinion and knowledge can be measured with statistically sound polls, initially and upon completion of the program.

The evaluation of the efficiency of the increased law enforcement effort will be difficult to measure, and must be reviewed by taking at least three different perspectives into consideration. These primary perspectives can be defined as: (1) deterrents caused by publicity and visibility of the program; (2) expectation of apprehension; and (3) enforcement and fishery statistics.

Specific criteria to evaluate success include:

1. Publicity (in various media) on the size and extent of the program;

2. Awareness by the public that law enforcement is greatly increased on Columbia and Snake river salmon runs;

3. Overt presence measured by increased numbers of uniformed officers in the field and total time spent on patrols;

4. Increased utilization of sophisticated communications and surveillance capabilities (ground, water, and air) of the la", enforcement force;

5. Increased use of inter-agency coordination and saturation task forces where problems exist (e.g., following the runs from the estuary to tributaries);

6. Increased number of arrests;

7. Increased number and percent of prosecutions, fines, and jail terms;

8. Increased equipment and fish seized;

9. Decreased market availability of illegal salmon as measured by covert operations;

10. Ability to estimate the extent of illegal harvest of salmon and steelhead throughout the Columbia Basin;

11. Decreased inter-dam loss that is attributable to decreased illegal harvest;

12. Increased numbers of adult spawners escaping to spawning areas.

\subsection{Adaptive Management - Programmatic Changes Required During 1995}


- Focus on habitat protection and screening violations had excellent compliance profile results and were therefore extremely successful in targeted areas during 1993 and 1994. Critical to the success of these efforts were the coordinated efforts of cooperating agencies and the local jurisdictions (counties). These efforts will be continued and expanded in 1995.

- The merger of the Departments of Fisheries and Wildlife into a combined agency will provide for the opportunity for increased baseline law enforcement, biological support, and coordinated ecosystem management throughout the project area.

- The Enforcement Program will continue to build upon compliance ratios to affect public attitudes and interaction with the resource. 

Chapter 4. Idaho Department of Fish and Game -- Project 92-024-04

\author{
Chief Frank NeSmith, \\ Project Administrator and Coordinator
}

(208) $334-3736$

\author{
Bureau of Law Enforcement \\ Idaho Department of Fish and Game \\ 600 S. Walnut Street, Box 25 \\ Boise, Idaho 83707
}

\title{
4.1 Introduction
}

In the summer of 1991, the Bonneville Power Administration (BPA) approached the Washington Departments of Fisheries and Wildlife (now the Washington Department of Fish and Wildlife) (WDFW), the Oregon State Police (OSP), the Columbia River Inter-Tribal Fisheries Enforcement (CRTFE) and the Idaho Department of Fish and Game (IDFG) with a proposal to enhance salmon protection in the Columbia River Basin.

This project was approved by BPA to start in September, 1991 with plans to run a demonstration period through December 31, 1994 and assess the impact of the enhanced enforced effort on depleted stocks of salmon. The goal was to give maximum protection to the remaining salmon stocks while management decisions to improve out and in migration of stocks was planned and implemented.

The rationale for a cooperative program involving the enumerated agencies was to provide for an enhanced capability of law enforcement beyond what was already being accomplished. This project would be dedicated to deterring stocks of salmon with this full time complement of manpower and equipment that could be used spread throughout the basin or concentrated in any problem area at any time. Coupled with this would be a strong and very visible information and education effort designed to elicit public support, and to ultimately save as many salmon as possible through the combined deterrent effect of a strong enforcement force that would be highly visible to the public on the water, and in the media.

The role of the combined efforts that all of the agencies have exerted in the Basin to protect salmon has been to give maximum protection to the runs as the adults migrate upstream and also when the smolts go downstream. This effort has never had a full time twelve month effectiveness due to other seasonal demands on the agencies and due to lack of proper equipment and manpower. 
Each agency has jurisdiction within its comprised geographic location within the basin that only overlaps as boundaries coincide. Within this project as manpower has been vacillated from ocean to spawning gravel and back, the lead agency within their geographical boundaries presents authority for enforcement and the officers from the other entities assist. This has answered the question of authority and prevented complaints of perceived problems that could arise when out of state officers might act in their own capacity.

In addition, the Idaho officers all carry U.S. Fish and Wildlife deputy commissions which gives them authority over federally listed endangered species in Oregon and Washington.

\subsection{Enhancements during the Demonstration Period Versus the 1991 Baseline}

Table 4.1 BPA Budget amount for the Idaho enhanced law enforcement project, by quarter, 1992 to 1994.

\begin{tabular}{|l|r|r|l|}
\hline \multicolumn{1}{|c|}{ Quarter } & $\mathbf{1 9 9 2}$ & $\mathbf{1 9 9 3}$ & \multicolumn{1}{c|}{$\mathbf{1 9 9 4}$} \\
\hline January-March & 9,465 & 125,572 & 196,245 \\
\hline April-June & 127,840 & 172,946 & 190,300 \\
\hline July-September & 117,562 & 235,449 & 192,583 \\
\hline October-December & 180,005 & 230,709 & 158,375 \\
\hline Annual Total & $\mathbf{\$ 4 3 4 , 8 7 2}$ & $\mathbf{\$ 7 6 4 , 6 7 6}$ & $\mathbf{\$ 7 3 7 , 5 0 3}$ \\
\hline
\end{tabular}

Table 4.2 Idaho enforcement personnel (FTE) in the Columbia Basin, by month, funded by BPA's enhanced law enforcement project, 11992-1994.

\begin{tabular}{|c|c|c|c|}
\hline Month & 1992 & 1993 & 1994 \\
\hline January & -- & $\begin{array}{l}\mathbf{5 . 0} \\
\$ 14,493\end{array}$ & $\begin{array}{l}\mathbf{5 . 0} \\
(1 \text { temp) } \\
\$ 17,929\end{array}$ \\
\hline February & - & $\begin{array}{l}\mathbf{5 . 0} \\
(0.5 \text { temp) } \\
\$ 16,340\end{array}$ & $\begin{array}{l}\mathbf{6 . 0} \\
(1 \text { temp) } \\
\$ 16,070\end{array}$ \\
\hline March & -- & $\begin{array}{l}\mathbf{5 . 0} \\
(0.5 \text { temp }) \\
\$ 17,918\end{array}$ & $\begin{array}{l}6.0 \\
(1 \text { temp) } \\
\$ 19,314\end{array}$ \\
\hline April & $\begin{array}{l}1.17 \\
\$ 3,639\end{array}$ & $\begin{array}{l}\mathbf{5 . 0} \\
(0.5 \text { temp) } \\
\$ 15.0,917 \\
\end{array}$ & $\begin{array}{l}\mathbf{6 . 0} \\
(1 \text { temp) } \\
\$ 20,861 \\
\end{array}$ \\
\hline May & $\begin{array}{l}\mathbf{5 . 0} \\
\$ 12,418\end{array}$ & $\begin{array}{l}\mathbf{5 . 0} \\
(0.5 \text { temp }) \\
\$ 16,590\end{array}$ & $\begin{array}{l}6.0 \\
(1 \text { temp) } \\
\$ 43,721^{*}\end{array}$ \\
\hline
\end{tabular}




\begin{tabular}{|c|c|c|c|}
\hline June & $\begin{array}{l}\mathbf{5 . 0} \\
\$ 13,029\end{array}$ & $\begin{array}{l}\mathbf{5 . 0} \\
(0.5 \text { temp) } \\
\$ 17,694\end{array}$ & $\begin{array}{l}6.0 \\
(1 \text { temp) } \\
\$ 21,460\end{array}$ \\
\hline July & $\begin{array}{l}\mathbf{5 . 0} \\
\$ 17,850\end{array}$ & $\begin{array}{l}\mathbf{5 . 0} \\
(0.5 \text { temp }) \\
\$ 30,675^{*}\end{array}$ & $\begin{array}{l}\mathbf{6 . 0} \\
(1 \text { temp) } \\
\$ 36,638\end{array}$ \\
\hline August & $\begin{array}{l}\mathbf{5 . 0} \\
\$ 16,402\end{array}$ & $\begin{array}{l}\mathbf{5 . 0} \\
(0.5 \text { temp) } \\
\$ 18,437 \\
\end{array}$ & $\begin{array}{l}\mathbf{6 . 0} \\
(1 \text { temp) } \\
\$ 24,193\end{array}$ \\
\hline September & $\begin{array}{l}5.0 \\
\$ 15,462\end{array}$ & $\begin{array}{l}\mathbf{5 . 0} \\
(0.5 \text { temp) } \\
\$ 18,066\end{array}$ & $\begin{array}{l}\mathbf{6 . 0} \\
(1 \text { temp) } \\
\$ 24,406\end{array}$ \\
\hline October & $\begin{array}{l}\mathbf{5 . 0} \\
\$ 16,349\end{array}$ & $\begin{array}{l}\mathbf{5 . 0} \\
(0.5 \text { temp) } \\
\$ 18,186 \\
\end{array}$ & $\begin{array}{l}\mathbf{6 . 0} \\
\text { (1 temp) } \\
\$ 23,412 \\
\end{array}$ \\
\hline November & $\begin{array}{l}\mathbf{5 . 0} \\
\$ 14,492\end{array}$ & $\begin{array}{l}\mathbf{5 . 0} \\
(0.5 \text { temp) } \\
\$ 18,167 \\
\end{array}$ & $\begin{array}{l}\mathbf{5 . 0} \\
\text { (1 temp) } \\
\$ 22,109 \\
\end{array}$ \\
\hline December & $\begin{array}{l}\mathbf{5 . 0} \\
\$ 21,670 *\end{array}$ & $\begin{array}{l}\mathbf{5 . 0} \\
(0.5 \text { temp) } \\
\$ 25,340^{*}\end{array}$ & $\begin{array}{l}\mathbf{5 . 0} \\
\text { (1 temp) } \\
\$ 29,584^{*}\end{array}$ \\
\hline
\end{tabular}

Denotes months with three pay periods. Monthly

fluctuations due to payroll adjustments, merit increases,

overtime and benefits.

\section{Inter-Agency Task Force}

The BPA Salmon Enforcement Team has emphasized the collective enforcement power and coordination that can produce single or many task force actions at any one time. Although there have been numerous small cooperative task forces between two or more agencies, in 1993 and 1994 major task force actions were formed to follow the major runs from the mouth of the Columbia River to spawning gravel in Idaho. Both of these operations, the one in 1993 being highly publicized and the one in 1994 not, have shown positive results. They have not only probably produced greater inter-dam conversion rates on adult salmon, but at the same time created a great amount of public support for the program. 
Table 4.3 Idaho conservation officers funded by the BPA Columbia Basin salmon enforcement program, 1994.

\begin{tabular}{|lll|}
\hline Name & Position & Location \\
Eldon Anglen & Senior Cons. Officer & Cottonwood \\
Jim Collom & Cons. Officer & Challis \\
Jon Heggen & Senior Cons. Officer & Yellowpine \\
Paul Valcarce & Senior Cons. Officer & Stanley \\
Rusty Middleton & Public Info Technician & Vancouver, \\
& & WA \\
Rod Nichols & Regional Cons. Educator & Lewiston \\
\hline
\end{tabular}

\section{$\underline{\text { Facilities }}$}

There are two residences in the program located at Yellowpine and Stanley. These were built because of a lack of readily available housing in these areas. Communication is by telephone, FAX, computer modems, two way and back country radios.

\subsection{Current Methods for Enforcement Data Collection and Management}

\section{Field Data Collection}

Field data are collected by not only the BPA salaried officers, but by all officers working anadromous fish in the system.

The data are collected monthly by use of the standard NMFS form approved by the CBLEC. These forms are sent through supervision to Boise Headquarters and then forwarded to the NMFS office at Astoria where the data are entered into a computer program designed to give the following information: Area Hours; Commercial Hours; Sport Hours; Ceremonial Hours; Habitat Hours; Aircraft Hours; Interagency Hours; Investigations; Salmon Seized; Steelhead Seized; Sturgeon Seized; Commercial Arrests; Sport Arrests; Nets Seized; Contacts; Public Relations.

This information is broken into the cooperating agencies and into the various geographical stretches of the system.

\section{Data Management System}

The data are verified and checked by each field supervisor and checked again at the Boise Headquarters level before it is submitted. The NMFS personnel provide feedback as to tardiness, incomplete forms and any essential items that may need attention.

\section{Data Analysis}

The data are used to show trends and effectiveness. Time spent per incident detected, hours in specific categories along with violation rates and rates of support for regulations can be 
calculated. Over a period of time these rates can determine problem areas, areas that might be emphasized less and overall efficiency of the program.

\subsection{Results}

Table 4.3 Enforcement statistics in Idaho, 1992-1994.

\begin{tabular}{|l|r|r|r|}
\hline \multicolumn{1}{|c|}{ Statistic } & $\mathbf{1 9 9 2}$ & $\mathbf{1 9 9 3}$ & $\mathbf{1 9 9 4}$ \\
\hline Ceremonial Hours & 345 & 317 & 142 \\
\hline Sport Hours & 5,989 & 7,814 & 6,464 \\
\hline Aircraft Hours & 35 & 43 & 39 \\
\hline Investigations & 318 & 316 & 155 \\
\hline Salmon Seized & 42 & 4 & 0 \\
\hline Commercial Arrests & 4 & 0 & 0 \\
\hline Sport Arrests & 309 & 245 & 152 \\
\hline Nets Seized & 6 & 1 & 0 \\
\hline Contacts & 6,840 & 7,369 & 5,874 \\
\hline Interagency Hours & 962 & 881 & 900 \\
\hline $\begin{array}{l}\text { Violation Detection } \\
\text { (compliance rate) }\end{array}$ & $5.89 \%$ & $3.32 \%$ & $2.59 \%$ \\
\hline Total Hours & 7,142 & 8,403 & 6,877 \\
\hline
\end{tabular}

In 1992, even though it is based on 8 months of data, shows a very enhanced effort in salmon enforcement. In 1993 we had the first major task force of following the runs from mouth to spawning gravel. The results of the enforcement action is evidenced in 1994 by the lowered violation activity and resulting time demands on the law enforcement personnel.

Another major factor that I consider is the officer's observations and reports. They have reported, starting in 1993, a much decreased human activity in those areas of spawning grounds and anadromous streams compared to the period prior to the project.

\subsection{Public Education and Awareness}

In attempting to increase public understanding of the problems facing Columbia Basin salmon, the public educators have pursued a twofold goal: to increase compliance with harvest regulations, and generate support for salmon recovery efforts including harvest law enforcement.

The enforcement strategy of the Salmon Enforcement Team focuses on deterrence. We have tried to contribute to the deterrence factor by publicizing the increased enforcement staffing and the acquisition of high-technology surveillance gear that have elevated enforcement presence in the basin. The improved compliance rates that were observed at the midpoint of the demonstration period can be attributed to a change in public perception: the would-be salmon poacher now thinks the risk of getting caught is much higher. The reality of tougher enforcement 
is responsible for this change in angler attitudes. The public information effort has complemented enforcement by keeping patrols, cases, and convictions in the news.

The public educators have served as liaisons with regional and national news media. A major press conference kicked off the first basin-wide emphasis patrol conducted by CBSET. Since then, we have maintained our contacts with reporters, providing them information about enforcement activities, and wherever possible arranging for them to ride along on boat and aerial patrols. Our news media contact list has expanded to several hundred names, including both regional and national media. Most of the coverage of CBSET field activities has been positive.

In some cases, media ride-along requests have exceeded enforcement capabilities, particularly FLIR flights and jet-boat patrols, due to limited available seating. Also, we have not been able to satisfy television reporters who have expectations of taping actual arrests, simply due to the nature of conservation law enforcement. Overall, the project agencies have been very cooperative in accommodating reporters on their patrols.

As with any new project, the newness eventually wore off and we had to seek new angles to maintain reporter interest. The Team's expansion into salmon habitat protection and pump station screening offered two fresh topics for news coverage. Reporters throughout the basin responded to project news releases and contacts by covering both these new emphases. Our theme in publicizing these issues was that CBSET provides the enforcement "muscle" to ensure compliance with environmental and fish screening regulations. CBSET's entry into habitat protection also boosted the project's credibility within the scientific community. While some fishery biologists look on traditional salmon harvest enforcement with a jaundiced eye, they see value in protection of salmon spawning and rearing habitats.

In an ongoing effort to apprise fishery managers and researchers of the goals and accomplishments of CBSET, we presented poster displays at major American Fisheries Society conferences throughout the basin. This interaction with salmon biologists has opened lines of communication that didn't exist previously between fishery enforcement professionals and fishery scientists. To reach the lay and sporting public, CBSET educators have made and staffed displays at sports shows. Staffing the exhibit booths with officers has enhanced this communications effort. Visitors to the booth appreciate direct contact with field officers, and they are able to obtain specific information about salmon enforcement that would be difficult to receive through any other means.

Streams where salmon play out key stages of the life cycle make good opportunities for on-site public education. With this in mind, the public educators have erected interpretive signs in several locations in the basin. The signs carry basic life history information about salmon and point out the importance of a particular location to their survival. In addition, each sign carries a message about the threats of poaching and habitat destruction and encourages visitors to contact one of the CBSET agencies to report violations.

Major highways border much of the salmon migration corridor, so we have tapped this "captive audience" of motorists via travelers information stations-- low-power radio stations that carry 
recorded messages 24 hours a day. Stations on the upper Salmon River and the lower Columbia River broadcast information about salmon and direct travelers to local sites of interest. Judging from letters received, the stations appear to be reaching a large number of travelers.

Public talks have been given to a wide cross-section of groups, from the Northwest Power Planning Council, to Bonneville Power Administration staff, to sportsmen's clubs, college classes, and elementary school children. While program content has been modified to fit each audience, the focus of the talks has been salmon endangerment, the role of harvest management in recovery, and the goals and activities of CBSET.

The educational thrust of the public awareness component is aimed at providing school teachers with resource materials they can use in the classroom. A series of activity leaflets written in late 1994 and currently being printed will give teachers a resource center with content on salmon life history, run decline, and recovery efforts, including harvest management. Video and slide programs produced on the project have been used extensively in teacher training workshops.

Because the salmon life cycle plays out over a vast geographical area, the biological and legal issues are complex and daunting. Many residents of the Pacific Northwest have retreated into inaction as a result. The salmon enforcement project has offered a clear-cut approach to aiding salmon recovery, within the context of harvest management. Unlike biological actions that often do not produce immediate, defined results, enforcement actions show direct cause-and-effect: poachers who get caught killing salmon are arrested and punished. Would-be poachers stay off the water altogether for fear of getting caught. The public educators have tried to convey the effectiveness of CBSET's efforts as a "good news story" that stands out amid the seeming paralysis of action that pervades the salmon issue on the biological and political fronts.

\subsection{Evaluation Plan}

Data collection and analysis will only be changed by CBLEC and a need to either delete some factors or add others. The current system is uniformly done and combines all agencies into a comparable base.

The measurement of enforcement effectiveness should be by quantifiable data and analysis of factors such as violations detected per hours spent and dam conversion rates. Officer opinions of effectiveness is very valid even though it is subjective. These observations should rank high in the overall analysis and measurement of effectiveness.

The inter-dam conversion rates should also be looked at as an enforcement measure as well as a biological benefit. It should still be stressed that this enforcement project's main function is to give maximum protection to anadromous fish while the runs remain low. Idaho plans to work with CBLEC \& NMFS to get necessary input, in a coordinated manner, to the Recovery Process. Idaho strongly recommends that the third party evaluation be used to give validity to the project. 


\subsection{Adaptive Management and Future Project Improvements}

This project has worked well enough that it is visioned as the best we can probably do with the combination of enforcement and information education. The project must remain at this level to keep these important safeguards on the endangered resource.

Idaho strongly suggests developing a forensics capability in the future to catalog the species for enforcement as well as biological purposes. With so many different runs of the same species of fish, it is imperative that a scientific basis is developed to support not only enforcement but the biological process as well. 


\title{
Chapter 5. National Marine Fisheries Service -- Project 92-024-05
}

\author{
David A. McKinney and Rod L. Moxley \\ National Marine Fisheries Service \\ 7600 Sand Point Way, N.E. F/EN6 \\ Seattle, Washington 98115
}

\subsection{Introduction}

National Marine Fisheries Service (NMFS), an agency of the U.S. Department of Commerce, National Oceanic and Atmospheric Administration, is responsible for over 29 different federal acts and statutes, including the Magnuson Fisheries Conservation and Management Act (MFCMA). Under the MFCMA, NMFS is charged with the management of all anadromous species throughout their migratory range, from the North Pacific Ocean to the Columbia River Basin (Basin). In 1991, under the Endangered Species Act (ESA), NMFS was designated by Congress as the lead agency having the responsibility of enforcing federal regulations on certain species of Snake River salmon. The authority for that responsibility is found in Section 7(a)(1), Endangered Species Act of 1973, USC $\$ 1531$ et seq., wherein federal agencies are mandated "...to utilize their authorities, in furtherance of the purposes of the Act by carrying out programs for the conservation of endangered species and threatened species listed pursuant to Section 4 of this Act." The Act specifically lists law enforcement as one of the conservation measures to be used to rebuild stocks to achieve de-listing. Snake River sockeye salmon were listed as endangered on Nov. 20, 1991. Snake River spring \& summer chinook and fall chinook salmon were listed as threatened on April 22, 1992. On Jan. 27, 1994, NMFS designated portions of the Columbia Basin as critical habitat and identified special management considerations, or protection, for the recovery of these fish. In the Proposed Recovery Plan for Snake River Salmon (Recovery Plan), law enforcement was one of several components given top priority in the recovery process.

The National Marine Fisheries Service Office of Enforcement is comprised of approximately 150 persons nationwide, including agents, uniformed officers and support staff. Geographically, NMFS is headquartered in the Washington, D.C., area and has offices in the United States, their Trusts and Territories. The Northwest Enforcement Division of NMFS is based in Seattle, WA and conducts enforcement activities in seven northwestern states, including Oregon, Washington, Idaho and Montana. Approximately 30 employees (agents, officers and support staff) are located in western Washington and Oregon. The goal of NMFS is not only to focus on the protection and enhancement of depleted salmon stocks that are listed as threatened or endangered under the ESA, but to promote, sustain and restore state, tribal and federal fisheries resources which inhabit the Columbia Basin for the benefit of the nation.

\footnotetext{
${ }^{4}$ Proposed Recovery Plan for Snake River Salmon, March, 1995, Department of Commerce, National Oceanic \& Atmospheric Administration, National Marine Fisheries Service, Chapter V, Section 5 - Enforcement: Recovery Tasks.
} 
NMFS Northwest Division is not alone in protecting these anadromous stocks. Specifically, salmon migrating between the Pacific Ocean and the Columbia Basin traverse private, state, tribal, federal and international jurisdictions, thus, numerous agencies are directly or indirectly involved in regulatory and enforcement mechanisms. Historically, in-river protection of salmon stocks in the Columbia Basin has been the responsibility of the states of Oregon, Washington and Idaho. Columbia River Inter-Tribal Fisheries Enforcement (CRITFE) is the fisheries law enforcement arm of the Columbia River Inter-Tribal Fish Commission (CRITFC) and bears the primary responsibility for enforcement of Treaty Indian fisheries in Zone 6 (between Bonneville and McNary dams on the Columbia River). The member tribes (Yakama, Warm Springs, Umatilla and Nez Perce) have law enforcement responsibilities on their main stem Treaty fishing areas, reservations, and ceded lands. These four tribes delegate partial authority for main stem fisheries enforcement to CRITFE, while maintaining their individual responsibilities on tributaries.

Since 1977, NMFS Enforcement Division has been actively involved in inter-agency cooperative efforts through the Columbia Basin Law Enforcement Council (CBLEC) to protect anadromous fish throughout their migratory range. CBLEC is an ad hoc council comprised of law enforcement representatives from Oregon, Washington, Idaho, Montana, Columbia River InterTribal Fish Commission, U.S. Fish and Wildlife Service, U.S. Coast Guard (USCG) and the National Marine Fisheries Service. Recently, the Shoshone-Bannock Tribe petitioned to join CBLEC. Initially, the emphasis was on the apprehension of illegal harvesters along the main stem of the Columbia River, utilizing the Lacey Act or existing state and tribal laws to prosecute violators. At the same time, routine coastal enforcement operations were being conducted yearly. Both of these efforts were successful, yet anadromous stocks continued in decline. In the late 80 's, recognizing the need for "Gravel to Gravel" protection of these stocks, NMFS initiated air (w/USCG \& Canadian Fisheries and Oceans) and sea patrols (w/USCG) on the high seas in the North Pacific; conducted undercover operations targeting international poachers; and expanded cooperative enforcement efforts through CBLEC in the Basin beyond the main stem of the Columbia River.

Bonneville Power Administration (BPA) began funding CBLEC agencies in 1992 for the Demonstration Period of CY92-94. However, NMFS did not enter into an Interagency Agreement (IA) with BPA to receive funding until September 1993. The objective of NMFS funding was to increase the overall effectiveness of NMFS in the Basin. Specifically to: 1. Provide law enforcement agents to enforce federal regulations related to Columbia Basin salmon stocks listed under the ESA, and to assist state and tribal fishery management agencies with enforcement of laws to protect anadromous salmonids throughout the Basin.

2. Provide specialized law enforcement equipment to assist state and tribal fishery management agencies in the enforcement of fishery harvest and habitat regulations to protect anadromous fish throughout the Columbia Basin.

3. Provide facilities (office space, supplies, boat storage, and equipment storage) to support inter-agency overt and covert planning operations, and deployment of multi-agency task forces -to increase law enforcement effectiveness for anadromous salmonids in the Columbia Basin. 4. Use the resources listed in items 1-3 above, to enhance the coordination of BPA's increased law enforcement grant activities with CBLEC agencies and cooperating entities. 
Because of the variety of jurisdictions in the Basin with concurrent enforcement responsibilities, CBLEC agencies committed themselves to working in a cooperative relationship. Perhaps the most visible and aggressive program developed under the auspices of CBLEC, in conjunction with BPA, is the Columbia Basin Salmon Enforcement Team (CBSET). This unit forms part of the multi-agency effort at the field level to protect endangered and threatened salmon. NMFS enforcement personnel participate in enforcement activities conducted by this unit. In addition, NMFS has provided space in their Vancouver office to house an Information \& Education employee assigned to the Salmon Enforcement Team.

\subsection{Enhancements during Demonstration Period versus 1991 Baseline.}

The following tables outline NMFS and BPA enhancements during the Demonstration Period, which include activities in the Columbia Basin, high seas, and coastal components. The costs are related to the equivalent of 4 FTEs performing these activities. 
Table 5.1 Budget -- non-expendable property category.

\begin{tabular}{|l|l|l|l|l|}
\hline ITEM & UNITS & COST PER UNIT & $\begin{array}{l}\text { NMFS } \\
\text { COST }\end{array}$ & $\begin{array}{l}\text { BPA } \\
\text { COST }\end{array}$ \\
\hline Office desks & 3 & 495 & 1,485 & - \\
\hline Office chairs & 3 & 367 & 755 & - \\
\hline Conference table & 1 & 625 & 625 & - \\
\hline Conference chairs & 14 & 237 & 3,318 & - \\
\hline Credenzas & 3 & 335 & 1,005 & - \\
\hline Book case & 3 & 159 & 477 & - \\
\hline File cabinet-3/drwr & 2 & 319 & 638 & - \\
\hline Cabinet-storage & 3 & 200 & 600 & - \\
\hline Cabinet - file/fax & 1 & 500 & 500 & - \\
\hline Desk Extension & 1 & 110 & 110 & - \\
\hline Sec. computer desk & 1 & 755 & 755 & - \\
\hline Secretary chair & 1 & 167 & 167 & \\
\hline Fax machine & 1 & 500 & 500 & - \\
\hline Typewriter & 1 & 350 & 350 & - \\
\hline $\begin{array}{l}\text { Computer (386), printer and } \\
\text { software }\end{array}$ & 1 & 4,500 & 4,500 & - \\
\hline $\begin{array}{l}\text { Telephone system (including } \\
\text { conference call system) }\end{array}$ & 1 & 4,000 & 2,000 & - \\
\hline Copy machine & 1 & & & - \\
\hline
\end{tabular}


Table 5.1 Budget -- non-expendable property category (continued).

\begin{tabular}{|c|c|c|c|c|}
\hline ITEM & UNITS & COST PER UNIT & $\begin{array}{l}\text { NMFS } \\
\text { COST }\end{array}$ & $\begin{array}{c}\text { BPA } \\
\text { COST }\end{array}$ \\
\hline Freezer, evidence & 1 & 300 & 300 & - \\
\hline Computers, notebook & 2 & 3,000 & 3,000 & - \\
\hline Raft, inflatable & 1 & 6,564 & 6,564 & - \\
\hline Videocam & 4 & 2,376 & 9,434 & - \\
\hline 24 ' Jet boat & 1 & 36,545 & 36,545 & - \\
\hline Outboard motor & 1 & 1,939 & 1,939 & - \\
\hline Night vision equip. & 4 & 5,513 & 22,052 & - \\
\hline Portable radios & 7 & 3,369 & 23,583 & - \\
\hline Car radio & 2 & 1,010 & 2,020 & - \\
\hline GPS unit & 1 & 500 & 500 & - \\
\hline Camera, $35 \mathrm{~mm}$ w/accessories & 1 & 1,130 & 1,130 & - \\
\hline Camera, pocket & 1 & 120 & 120 & - \\
\hline Camping gear, misc. & 1 & 1,285 & 1,285 & - \\
\hline Binoculars & 1 & 275 & 275 & - \\
\hline Handgun, S\&W 4048 & 1 & 575 & 575 & - \\
\hline Tape recorder & 1 & 70 & 70 & - \\
\hline Tool box w/tools & 1 & 200 & 200 & - \\
\hline Depth finder & 1 & 150 & 150 & - \\
\hline Handgun safety box & 1 & 75 & 75 & - \\
\hline $\begin{array}{l}\text { Rifle, Winchester model 70, } \\
30-06\end{array}$ & 1 & 400 & 400 & - \\
\hline Subtotal & - & - & 106,917 & NONE \\
\hline
\end{tabular}


Table 5.1 Budget -- operation and maintenance category.

\begin{tabular}{|c|c|c|c|c|}
\hline ITEM $^{5}$ & UNITS & COST PER UNIT & $\begin{array}{l}\text { NMFS } \\
\text { COST }\end{array}$ & $\begin{array}{c}\text { BPA } \\
\text { COST }\end{array}$ \\
\hline Office/warehouse lease & $\begin{array}{l}1992 \\
1993 \\
1994\end{array}$ & $\begin{array}{l}\text { none* } \\
17,088 \mathrm{yr} \\
17,172 \mathrm{yr}\end{array}$ & - & 34,260 \\
\hline $\begin{array}{l}\text { Meeting Room rental } \\
1992 \text { (none) } \\
1993 / 94 \text { ( } 24 \text { days) }\end{array}$ & 24 days & 35/day & - & 840 \\
\hline Directory (one time cost) & $\begin{array}{l}1 \text { st yr } \\
1993\end{array}$ & 468 & - & 468 \\
\hline $\begin{array}{l}\text { Janitorial } \\
1992 \text { (none) }\end{array}$ & $\begin{array}{l}24 \mathrm{mos} \\
93 / 94\end{array}$ & 195 & - & 4,680 \\
\hline Subtotal & - & - & NONE & 48,144 \\
\hline
\end{tabular}

*BPA funding was used to pay the expenses of leasing the NMFS Vancouver, WA office that opened Feb. 1993. Prior to that, the NMFS FTE dedicated to Columbia Basin enforcement was co-located with other NMFS personnel in Portland, OR at no cost to the Enforcement Division or to BPA.

Table 5.1 Budget -- supplies, equipment, and training category.

\begin{tabular}{||l|c|c|c|c|}
\hline \multicolumn{1}{|c|}{ ITEM } & UNITS & COST PER UNIT & $\begin{array}{c}\text { NMFS } \\
\text { COST }\end{array}$ & $\begin{array}{c}\text { BPA } \\
\text { COST }\end{array}$ \\
\hline \hline Field supplies & - & - & 5,000 & - \\
\hline Office supplies & - & - & 4,000 & - \\
\hline \hline Subtotal & - & - & 9,000 & NONE \\
\hline
\end{tabular}

\footnotetext{
${ }^{5}$ Lease and utilities are separate procurement instruments between BPA and the lessor/service providers.
} 
Table 5.1 Budget -- travel category.

\begin{tabular}{|c|c|c|c|c|}
\hline ITEM & UNITS & COST PER UNIT & $\begin{array}{l}\text { NMFS } \\
\text { COST }\end{array}$ & $\begin{array}{c}\text { BPA } \\
\text { COST }\end{array}$ \\
\hline $\begin{array}{l}\text { Enforcement operations } \\
\text { 1992-1994 }\end{array}$ & $3 \mathrm{yrs}$ & - & 12,000 & - \\
\hline Subtotal & - & - & 12,000 & NONE \\
\hline
\end{tabular}

Table 5.1 Budget -- services and subcontracts category.

\begin{tabular}{|c|c|c|c|c|}
\hline ITEM & UNITS & COST PER UNIT & $\begin{array}{c}\text { NMFS } \\
\text { COST }\end{array}$ & $\begin{array}{c}\text { BPA } \\
\text { COST }\end{array}$ \\
\hline $\begin{array}{l}\text { Lease of four (4) vehicles, } \\
\text { including oper/maint expenses }\end{array}$ & 3 yrs & 29,428 & 88,284 & - \\
\hline \hline Subtotal & - & - & 88,284 & NONE \\
\hline
\end{tabular}

Table 5.1 Budget - indirect costs (personnel, services, and supplies) category.

\begin{tabular}{|c|l|l|c|}
\hline PERSONNEL & RATE & $\begin{array}{l}\text { NMFS } \\
\text { COST }\end{array}$ & $\begin{array}{l}\text { BPA } \\
\text { COST }\end{array}$ \\
\hline \hline $\begin{array}{l}\text { 4 FTEs FY92-94 (one full- } \\
\text { time, three equivalent) }\end{array}$ & 100,000 per FTE/yr & $1,200,000$ & - \\
\hline Subtotal & - & $1,200,000$ & NONE \\
\hline
\end{tabular}

\section{BUDGET TOTAL: FY92/94}

\begin{tabular}{|c||c|}
\hline NMFS COST & BPA COST \\
\hline \hline$\$ 1,416,201$ & $\$ 48,144^{*}$ \\
\hline
\end{tabular}

* The first BPA/NMFS Interagency Agreement (IA) was implemented for the period September 1993 through December 31, 1994, with a total BPA-allocated funding of $\$ 90,582$. However, during the FY92-94 Demonstration Period, NMFS utilized BPA funds for only the OPERATION 
AND MAINTENANCE expenses ( $\$ 48,144$ for Vancouver, WA office space lease). All other costs associated with salmon recovery activities in the Columbia Basin, and the coastal and high seas components during the Demonstration Period were absorbed by NMFS Northwest Law Enforcement Division. NMFS further anticipates that BPA funding will not be utilized by the Enforcement Division in the future. ${ }^{6}$ Since there was a carry-over of $\$ 31,131$ in unused FY94 funds into FY95, the Northwest Enforcement Division received approval from BPA to use that money, plus an additional $\$ 7,347$ of FY95 BPA allocation, to purchase a $20^{\prime}$ aluminum river boat to be turned over to CBLEC. The patrol craft will be located, maintained, and assigned to CRITFE and under their control at all times for purposes of accountability. However, as a condition of this purchase, CRITFE agrees to allocate proportional usage to all other CBLEC agencies, as appropriate. NMFS is seeking long-term federal funding for its Columbia Basin enforcement activities and does not anticipate the need for future BPA funding.

Table 5.2 Law enforcement personnel in the Columbia Basin.

\begin{tabular}{|c|c|c|c|}
\hline $\begin{array}{l}\text { 1991 BASELINE } \\
\text { PERSONNEL IN } \\
\text { THE COLUMBIA } \\
\text { BASIN }\end{array}$ & $\begin{array}{l}\text { ADDITIONAL } \\
\text { BPA FUNDED } \\
\text { FTES FOR } 1992 \\
\text { (OVER 1991 } \\
\text { BASELINE) }\end{array}$ & $\begin{array}{l}\text { ADDITIONAL } \\
\text { BPA FUNDED } \\
\text { FTES FOR } 1993 \\
\text { (OVER 1991 } \\
\text { BASELINE) }\end{array}$ & $\begin{array}{l}\text { ADDITIONAL } \\
\text { BPA FUNDED } \\
\text { FTES FOR } 1994 \\
\text { (OVER 1991 } \\
\text { BASELINE) }\end{array}$ \\
\hline 1 & $\varnothing$ & $\varnothing$ & $\varnothing$ \\
\hline
\end{tabular}

PERSONNEL - Vancouver, WA

1991 to present: David K. Johnson, Special Agent (1.0 FTE)

(Augmented by the equivalent of 3 additional FTEs)

Since Feb. 1995: Rod L. Moxley, Senior Special Agent (1.0 FTE)

In 1991, NMFS transferred one FTE (Special Agent) to Vancouver, WA, tasked full time with the duty of coordinating/facilitating inter-agency enforcement activities in the Columbia Basin. The position was fully funded by NMFS through the Demonstration Period, and no additional FTEs were added to the Columbia Basin during that period ${ }^{7}$. However, during the Demonstration Period, an equivalent of 3 FTE enforcement personnel from other offices in the Northwest Region were used to augment Columbia Basin enforcement. This included agents and officers detailed on assignments in the Basin, on coastal/near shore operation and on aerial and sea patrols in the North Pacific.

\footnotetext{
6 The only exception is the continued funding of the Vancouver office space by BPA through 1995, and the expenditure for the $20^{\prime}$ river boat in FY95.

${ }^{7}$ In February 1995, the second FTE posilion (supervisor) was added to the Vancouver office to direct the NMFS enforcement program associated with the Recovery Plan for Snake River Salmon. Additional positions for enforcement agents at Boise and Lewiston, Idaho will be filled upon authorization of funding. Also, a half-time data technician position in Vancouver, WA is expected to be filled by FY96, dedicated to the Columbia Basin. None of these positions will utilize BPA funding.
} 


\subsection{Current Methods for Enforcement Data Collection and Management}

Each member agency of CBLEC maintains their own unique system of data collection of their enforcement activities for internal purposes. In addition, each agent/officer working in the Basin is required to submit through their chain of command a separate CBLEC Columbia River Individual Activity Report (CRIAR). CRIER reports are forwarded to Astoria, OR for entry into a computer data collection system maintained by NMFS support staff. This data has been collected since 1985, and it is manually verified and entered by the staff member into an RBASE computer program. Reports are generated annually, and as needed by various agencies. NMFS recognizes the need for a reliable data base in order to accurately assess enforcement effort and levels of compliance, and has purchased the latest computer equipment. The data system is under review, and an enhanced system will be implemented to provide that ability. Data collection services will be transferred to the Vancouver office by the end of the year, and a part-time data technician will be hired to manage the system.

\subsection{Results}

During the Demonstration Period, NMFS Enforcement provided agents to assist the states and tribes with enforcement of laws to protect salmon in the Basin; provided specialized equipment to the states and tribes in the enforcement of harvest and habitat regulations; provided facilities to support inter-agency overt and covert planning operations, and deployment of multi-agency task forces; and utilized all of the above resources to enhance the coordination of BPA's increased law enforcement grant activities with CBLEC.

During the Demonstration Period, NMFS conducted enforcement activities in the Basin, along the coastal zones off Oregon and Washington, and on the high seas to provide "Gravel to Gravel" protection of Columbia Basin salmonids. The high seas component involved vessel and aircraft patrols with the U.S. Coast Guard, and aerial patrols with Canadian Fisheries and Oceans. The coastal enforcement component involved sea \& air patrols the U.S. Coast Guard; and sea, air and land operations with CBLEC member states. In the Basin, NMFS conducted its enforcement operations with all participating members of CBLEC, including town hall meetings and other public relations activities. During the Demonstration Period, NMFS utilized the equivalent of 4 fulltime employees for each of those years in "Gravel to Gravel" enforcement activities.

During this reporting period the Northwest Enforcement Division:

- Increased the level of harvest protection through an increase in the level of detection and deterrence of violations.

- Increased the level of cooperation among state, tribe, federal and local entities in the Basin.

- Increased public awareness through town hall meetings and other forums.

\subsection{Evaluation plan}

NMFS recognizes the need to improve on current data collection. Additional elements of reporting will be identified and incorporated into the current system as needed. Consistency and 
uniformity at the field level in documenting all CBLEC-coordinated enforcement activities will continue to be a priority to ensure that the data are an accurate base from which reliable measurements can be taken. Reports will go out to each member agency on a monthly and yearly basis. They will be made available to fishery managers, and to others upon request. Additional reports will be provided according to specific needs of individual agencies.

\subsection{Adaptive Management and Future Project Improvements}

NMFS Northwest Enforcement Division has historically worked cooperatively with states and tribes to protect anadromous fish in the Basin. Early on NMFS recognized that enforcement efforts needed to be implemented through a "Gravel to Gravel" approach, rather than to be narrowly focused on just the main stem of the Columbia River and along coastal waters. For the past several years NMFS has been conducting and facilitating cooperative salmon enforcement operations in the North Pacific Ocean, along the coastal waters and throughout the Columbia Basin. The listing of the Snake River sockeye salmon as endangered in Nov. 1991, the spring \& summer chinook salmon as threatened in April 1992, and the advent of the Recovery Plan in March 1995, has further increased the necessity for a strong "Gravel to Gravel" enforcement role by NMFS.

With an ever increasing concern, the recent events in the Pacific Northwest point to the need for mechanisms to enhance the Columbia Basin Law Enforcement Council efforts: the prosecution of the "Gravel-to-Gravel" enforcement strategy for listed and unlisted salmon stocks; the advent of the Snake River Recovery Plan; increasingly limited fiscal and personnel resources for enforcement efforts; and shifting public administration paradigms calling for streamlining, teamwork, and performance-based measurement. To meet these needs, CBLEC has prepared a Strategic Enforcement Plan based upon a 5 year planning horizon. This plan emphasizes the strengthening and expansion of salmon enforcement management, the expansion of enforcement public outreach programs, and the expansion of coordination and team support amongst Columbia Basin enforcement agencies. In terms of the Proposed Snake River Salmon Recovery Plan, NMFS NW Enforcement Division's objective is to prevent losses of listed salmon throughout their range. The "Gravel-to-Gravel" objective involves not only enforcement in the Columbia Basin, but also in the coastal and North Pacific fisheries components. This can be ensured by:

- Increasing the presence of law enforcement. CBLEC enforcement agencies should increase the number of patrols on selected portions of rivers and streams to identify unreported and illegal activities that are detrimental to salmon survival.

- Increasing public awareness and compliance through increased public seminars, town hall meetings, presentations and publications concerning the enforcement strategy in the Basin.

- Enforcing existing federal laws. Including the promulgation by NMFS and FWS Enforcement Divisions of federal regulations consistent with existing state and tribal regulations that are more effective for enforcement.

- Ensuring that the "Gravel to Gravel" approach continues by incorporating all participating enforcement organizations into the strategic paradigm under the auspices of CBLEC. The NMFS Northwest Enforcement Division should implement a computer-based communications system and a standardized data base for gathering and organizing information related to multiagency enforcement activity. 
Chapter 6. Montana Department of Fish, Wildlife, \& Parks-- Project 92-024-06

\author{
Mack Long, Game Warden Captain \\ Montana Department of Fish, Wildlife, and Parks \\ 3201 Spurgin Road \\ Missoula, Montana 59801
}

\title{
6.1 Introduction
}

The State of Montana is concerned about a number of its resident native fish. These indigenous fish populations include: bull trout (Salvelinus confluentus), white sturgeon (Acipenser transmontanus), westslope cutthroat (Oncorhynchus clarki lewisi), red band rainbow (Oncorhynchus mykiss subspecies) and arctic grayling (Thymallus arcticus).

We have enacted a bull trout restoration team which includes State, Federal, Tribal and private interests, all dedicated to restoring bull trout in western Montana. The major bull trout drainages have been identified and enforcement plan has been implemented to protect these areas. The key ingredients of this plan are the acceptance and commitments of all participants.

The overall goal is to increase the perception of the value of the bull trout, not only as a resident fish, and not because the law may require the fish be recovered, but because the fish is one example of our collective stewardships. The goal of this system-wide law enforcement program is to reduce illegal harvest of all fish especially endangered, warranted or stressed fishes in Montana.

The bull trout was petitioned for protection under the ESA and was found to be "Warranted but precluded." It appears now that this has been challenged and listing will occur soon. Bull trout populations have declined significantly in recent years. Spawning redd numbers are at historic lows making each pair of spawning bull trout extremely important. Studies have shown that illegal harvest in conjunction with environmental and habitat degradation are seriously impacting recovery efforts.

The Kootenai White Sturgeon been listed as endangered under the ESA. Again illegal harvest along with environmental and habitat degradation is a continued threat to their survival. Due to this fishes docile nature, they are very susceptible to poaching.

Several other fish are also in need of special protection. Each of these species listed above are in need of increased levels of protection.

\section{Montana's Enforcement Goal}

The ultimate goal of the program in Montana is to reduce illegal harvest of resident fishes and increase protection of ESA species. The approach we are taking is threefold: first, to substantially increase and maintain enhanced levels of enforcement on the water. This would be above present 
baseline levels. This will result in increased prosecutions and will serve as a deterrent to future poaching; secondly, to enhance this increased effort by promoting cooperation and assistance from appropriate federal, state, tribal, regional and local entities; and thirdly, to educate the public on the plight of specific populations that are in danger of extinction and the importance to society of conserving the values and diversity of Montana's resident fishes for future generations.

\section{Rationale for BPA Enhanced Law Enforcement Program}

At the current time there are limited state budgets available for the enforcement of resident and ESA fishes. Through BPA's enhanced enforcement program the levels of protection which the resource and the public demand are being addressed. Montana is in it's first year of this program and received a minimal level of funding, but already positive results are being felt.

\section{Role of Law Enforcement in Columbia Basin Fish Restoration}

Enforcement is a critical element in any fish or wildlife management program. Especially when populations are at critically low estimates, each pair of spawners are essential to the species survival. Several species in the Columbia Basin will benefit from these enhanced efforts.

Enforcement also carries another responsibility of educating the public. This is also essential if the program is going to work in recovering the fish.

\section{Jurisdiction, Statutory Authority, and Inter-Agency Cooperation}

A key element in the overall BPA program is the cooperation among the CBLEC members. The enhanced ability to exchange information and resources in very valuable. This alone could deter some would be poachers from violating the law. The shared personnel can address peak user times which correspond with spawning periods of the fish. When officers from other states are working in Montana they will be assigned to a local team which will provide a legal basis for arresting violators.

\subsection{Current Methods for Enforcement Data Collection and Management}

\section{Field Data Collection}

Field data are collected by all wardens working in the Columbia River Basin of Western Montana, The area comprises Region One and Region Two of the Department of Fish, Wildlife, and Parks' seven regions. Field wardens submit monthly reports through the supervisors of their respective regions to Helena Headquarters.

Data collection was not sufficiently modified to accurately reflect the total enforcement effort directed at restoration of bull trout and white sturgeon. As a result, this necessitated that field wardens review prior activities logs and submit a record of enforcement activities directed toward designated species for the reporting period to their respective supervisor. 


\section{Data Management System}

Field data are collected by all officers working bull trout and white sturgeon areas and reports are submitted on a monthly basis through his/her supervisor to Helena Headquarters, Data specifically related to bull trout and white sturgeon is maintained by these supervisors and entered on computer programs designed to give the following information: arrests, written warnings (CC'), verbal warnings, fish seized, sports-person contacts and public relations,

\section{Data Analysis}

Data are used to show trends and effectiveness. Compliance rates will indicate rates of support for regulations and when combined with biological data, these rates can determine problem areas or areas that might be emphasized less.

\subsection{Results}

Table 6.1 Statistics on bull trout enforcement in Montana, 1993-1994.

\begin{tabular}{|l|c|c|}
\hline Statistic & $\begin{array}{c}1993 \\
\text { (Pre-BPA) }\end{array}$ & $\begin{array}{c}1994 \\
\text { July-December }\end{array}$ \\
\hline Arrests & -- & 24 \\
\hline Written Warnings & - & 13 \\
\hline Verbal Warnings & -- & 80 \\
\hline Contacts & -- & 1834 \\
\hline Bull Trout Seized & -- & 21 \\
\hline Compliance Rate & -- & $93.6 \%$ \\
\hline
\end{tabular}

\section{Public Education and Awareness}

With the additional funds provided by BPA, we will enhance our enforcement efforts by implementing a number of Information and Education (I\&E) strategies concerning these indigenous fish, i.e., issuing bull trout identification cards, warden contacts with sportsmen/women, fair displays, school programs, media contacts, angler education classes, etc.

By utilizing these programs, we will increase the public visibility concerning the protection of the resident fish from over-harvest, incidental catches and illegal harvest. For those who are reluctant to embrace this concept, we are committed to "the expectation of being caught" principle. For those who violate the resource protection measures now in place, we have increased the presence of uniformed officers and have implemented covert and overt investigations during the critical spawning, rearing and migratory movements of these fish. These increased efforts will have the 
following results: slow, change or stop illegal activity, The net effect will be more adult spawners and survival of juveniles to spawning age. the efforts, tied with increased I\&E work will lead to a higher visibility for all resource users. A well-informed and committed public is the determining factor in the success of this program.

\subsection{Evaluation Plan}

\section{Improvements in data collection and analysis}

The present Warden Monthly Service Record is being revised to more accurately reflect warden accomplishments, duties and the time spent to perform these duties. An additional form will be used to collect information to accurately reflect the enforcement effort specific to resident species and compatible with the data base maintain by NMFS.

\section{Measurement of Enforcement Effectiveness}

Success of the enhanced law enforcement program will be measured by an increase in compliance rate and by increase in redds and/or survival of juvenile, sub-adult and adult fish. The acceptance of more stringent regulations, the ability to identify species and the perceived value of indigenous fish by the public will determine the overall and long term success of this program.

\section{Measurement of Biological Benefits}

The major objective is the restoration of indigenous fish population of bull trout and white sturgeon. Monitoring changes in juvenile and sub-adult survival and number of redds or spawning adults will provide a basis for quantitative evaluation of an enhanced law enforcement effort. A long term data base should be established to rule out factors creating short term effects on any or all categories of survival of populations, such as dry years or increased sedimentation from forest fires. These factors are important but must be separated from the law enforcement effort for proper evaluation of the program.

\subsection{Adaptive Management and Future Project Improvements}

Current enforcement information will establish a baseline for evaluation of the long-term effect of restrictive regulations for the restoration of bull trout and white sturgeon. Collection of additional data with improved forms will allow project leaders to make necessary changes to eliminate ineffective components, reduce redundancies and increase cost effectiveness.

Biological information should indicate compliance with restrictive regulations as well as areas of potential poaching. For example, an increase in the number of redds and surviving juveniles will indicate a compliance with regulations while the lack of an increase in redds or juveniles in important spawning tributaries may indicate poaching. 
Some project improvements and additions are:

1. Educate law enforcement personnel on the biology and distribution of bull trout and white sturgeon.

2. Improve the exchange of information between biologists and field wardens about changes in populations, areas of suspected poaching or population concerns.

3. Annual evaluation of data, data collection needs, methodology and problem areas.

4. Annual meeting between wardens and biologists to share information about changes in populations, distribution, regulations and problem areas. 



\section{APPENDIX 1. REFERENCES}

Bevan, D., J. Harville, P. Bergman, T. Bjornn, J. Crutchfield, P. Klingeman, and J. Litchfield. 1994. Snake River Salmon Recovery Team: final recommendations to the National Marine Fisheries Service. May 1994. Rob Jones, Recovery Plan Coordinator. National Marine Fisheries Service, Portland, Oregon.

Chris, Inc. 1994. Phase II Fish Screen inspection program, Columbia River. Final Report to Oregon Department of State Police, Salem, Oregon.

Harrison, J. 1993. Eco-cops. Northwest Energy News Volume 12, No. 3. March/April 1993. Northwest Power Planning Council, Portland, Oregon.

Kraft, Larry. 1993. Letter to Captain John Johnson, Chairman, Columbia River Inter-Tribal Fish Commission. July 19, 1993. Oregon State Police, Salem, Oregon.

Northwest Power Planning Council (NPPC). 1992. Columbia River Basin Fish and Wildlife Program Amendment -- Strategy for Salmon Volume II. Publication 92-21A. Northwest Power Planning Council, Portland, Oregon.

Musgrave, R.S., S. Parker, and M. Wolok. 1993. The status of poaching in the United States. Natural Resources Journal Vol.33 (Fall):977-1014.

Pella, J., R. Rumbaugh, L. Simon, M. Dahlberg, S. Pennoyer, and M. Rose. 1993. Incidental and illegal catches of salmonids in North Pacific driftnet fisheries. In: Ito, J., W. Shaw, and R.L. Burgner (eds.), Catch and fishery impact (all species). Bulletin Number 53(III). International North Pacific Fisheries Commission. Symposium on biology, distribution and stock assessment of species caught in the North Pacific Ocean, held at Tokyo, Japan. November 4-6, 1991. Vancouver, Canada. 576 pp.

Storment-Ray \& Assoc., Inc. 1993. Subcontract report, March 23, 1993 to Lt. Larry Kraft, Oregon State Police, Salem, Oregon.

Swan, G. 1981. Columbia River pump survey. National Marine Fisheries Service, CZES, Seattle, WA.

Vigg, S. 1991. Increased levels of fishery harvest law enforcement and public awareness for anadromous salmonids in the Columbia River Basin. Grant Proposal and Project Description for Columbia River Inter-Tribal Fish Commission, Oregon Department of State Police, Washington Departments of Fisheries and Wildlife, and Idaho Department of Fish and Game. Bonneville Power Administration, Portland, Oregon.

Vigg, S. 1993. Increased levels of fishery harvest law enforcement and public awareness for anadromous salmonids in the Columbia River Basin, Project 92-024, Part 5.0. An Interagency Agreement with the National Marine Fisheries Service, Office of Law 
Enforcement to provide: Interagency Task Force Coordination and ESA-related Support for the Columbia River Basin Salmon Enforcement Team. August 11, 1993. Bonneville Power Administration, Portland, Oregon.

Vigg, S. 1994. Increased levels of harvest \& habitat law enforcement and public awareness for anadromous salmonids and resident fish in the Columbia River Basin. Project 92-024. Project Description for a comprehensive Columbia Basin cooperative Law Enforcement Program comprised of six Grants and Inter-Agency Agreements with: Columbia River Inter-Tribal Fish Commission, Oregon Department of State Police, Washington Department of Fish and Wildlife, Idaho Department of Fish and Game, National Marine Fisheries Service, and Montana Department of Fish, Wildlife \& Parks. December 31, 1994. Bonneville Power Administration, Portland, Oregon. 
APPENDIX 2. SUMMARY OF ANADROMOUS AND RESIDENT FISH SPECIES IN THE COLUMBIA BASIN THAT ARE LISTED, PETITIONED, OR POTENTIAL CANDIDATES UNDER THE ENDANGERED SPECIES ACT AS OF 1994.

\begin{tabular}{|c|c|c|c|}
\hline $\begin{array}{l}\text { Common Name of Stock } \\
\text { (ESA species/Evolutionarily } \\
\text { Significant Unit, ESU) }\end{array}$ & Biological Species Name & ESA Status & $\begin{array}{l}\text { Geographic } \\
\text { Spawning } \\
\text { Range }\end{array}$ \\
\hline \multicolumn{4}{|l|}{ Anadromous Fish: } \\
\hline Snake River sockeye salmon & Onchorhynchus nerka & Endangered & $\begin{array}{l}\text { Redfish } \\
\text { Lake, ID }\end{array}$ \\
\hline $\begin{array}{l}\text { Snake River fall chinook } \\
\text { salmon }\end{array}$ & Onchorhynchus tshawytscha & Endangered & OR, WA, ID \\
\hline $\begin{array}{l}\text { Snake River spring/summer } \\
\text { chinook salmon }\end{array}$ & Onchorhynchus tshawytscha & Endangered & OR, WA, ID \\
\hline Coastwide coho salmon & Onchorhynchus kisutch & Status Review & $\begin{array}{l}\text { OR, WA, } \\
\text { ID, CA }\end{array}$ \\
\hline Coastwide steelhead & Onchorhynchus mykiss spp. & Status Review & $\begin{array}{l}\text { OR, WA, } \\
\text { ID, CA }\end{array}$ \\
\hline Coastwide chinook salmon & Onchorhynchus tshawytscha & Status Review & $\begin{array}{l}\text { OR, WA, } \\
\text { ID, CA }\end{array}$ \\
\hline Coastwide pink salmon & Onchorhynchus gorbuscha & Status Review & $\begin{array}{l}\text { OR, WA, } \\
\mathrm{ID}, \mathrm{CA}\end{array}$ \\
\hline Coastwide chum salmon & Onchorhynchus keta & Status Review & $\begin{array}{l}\text { OR, WA, } \\
\text { ID, CA }\end{array}$ \\
\hline Coastwide sockeye salmon & Onchorhynchus nerka & Status Review & $\begin{array}{l}\text { OR, WA, } \\
\text { ID, CA }\end{array}$ \\
\hline $\begin{array}{l}\text { Coastwide sea-run cutthroat } \\
\text { trout }\end{array}$ & Onchorhynchus clarki clarki & Status Review & $\begin{array}{l}\text { OR, WA, } \\
\text { ID, CA }\end{array}$ \\
\hline \multicolumn{4}{|l|}{ Resident Fish: } \\
\hline Kootenai River white sturgeon & Acipenser transmontanus & Endangered & $\begin{array}{l}\text { Kootenai } \\
\text { River/Lake } \\
\text { MT, ID, BC }\end{array}$ \\
\hline Bull trout & $\underline{\text { Salvelinus confluentus }}$ & $\begin{array}{l}\text { Warranted but } \\
\text { precluded }\end{array}$ & $\begin{array}{l}\text { OR, WA, } \\
\text { ID, MT }\end{array}$ \\
\hline Red Band rainbow trout & Onchorhynchus mykiss spp. & Status Review & $\mathrm{OR}, \mathrm{ID}, \mathrm{MT}$ \\
\hline Westslope cutthroat trout & Onchorhynchus clarki lewisi & depleted & $\mathrm{ID}, \mathrm{MT}$ \\
\hline Lahontan cutthroat trout & $\begin{array}{l}\text { Onchorhynchus clarki } \\
\text { henshawi }\end{array}$ & Threatened & NV, WA \\
\hline Burbot & Lota lota & depleted & $\begin{array}{l}\text { OR, WA, } \\
\text { ID, MT }\end{array}$ \\
\hline Kokanee & Onchorhynchus nerka spp. & depleted & ID, MT \\
\hline Artic grayling & Thymallus arcticus & depleted & ID, MT \\
\hline
\end{tabular}



Appendix 3. List of Presentations, Publications and News Releases.

Table A3-1. Summary of news releases, publications, and slide/video presentations done by the two project public educators. \{These totals do not include related news releases and presentations made by project enforcement officers during the three-year demonstration period\}.

\begin{tabular}{|l|c|}
\hline \multicolumn{1}{|c|}{ Information Media } & Number \\
\hline News releases & 37 \\
\hline brochures & 4 \\
\hline fact sheets & 2 \\
\hline Presentations & 34 \\
\hline Radio interviews & 16 \\
\hline Interpretive signs & 9 \\
\hline Poster Displays built & 4 \\
\hline $\begin{array}{l}\text { Posters presented (sport shows \& } \\
\text { conferences) }\end{array}$ & 7 \\
\hline Magazine articles published & 2 \\
\hline
\end{tabular}


Table A3-2. News release headlines and dissemination dates.

\begin{tabular}{|c|c|}
\hline Date & News Release - Topic \\
\hline $4 / 3 / 92$ & Anglers Note: The Trout You Catch May Be A Salmon \\
\hline 9/3/92 & Fish \& Game Sting Breaks Up Wildlife Poaching Ring \\
\hline 9/10/92 & Steelheaders Advisory: Know Your Catch \\
\hline $1 / 23 / 93$ & Conservation Officers Turn Up The Heat On Salmon Poachers \\
\hline $1 / 26 / 93$ & $\begin{array}{l}\text { "If our salmon runs are in so much trouble, why can I buy fresh } \\
\text { salmon at Albertson's?" }\end{array}$ \\
\hline $2 / 25 / 93$ & Salmon Enforcement Team To Track Endangered Sockeye Run \\
\hline $4 / 30 / 93$ & Night-Vision Device Brings Poachers To Light \\
\hline $5 / 10 / 93$ & Is That Trout Really A Trout? \\
\hline $5 / 12 / 93$ & State And Tribal Officers Cooperate on Salmon Bust \\
\hline $6 / 8 / 93$ & Media Advisory: Vancouver Press Conference \\
\hline $6 / 11 / 93$ & Fishery Officers Plan 900-Mile Salmon Patrol \\
\hline $6 / 14 / 93$ & Pump Station Survey Aims To Reduce Salmon Losses \\
\hline $6 / 24 / 93$ & Infrared Eyes Spy Sturgeon Poacher \\
\hline $6 / 24 / 93$ & Multi-Agency Salmon Patrol Heads Up Columbia River \\
\hline $6 / 30 / 93$ & Angler Cited For Defrauding Squawfish Reward Program \\
\hline $7 / 14 / 93$ & Salmon Patrol Slams Poachers In Tri-Cities Area \\
\hline $8 / 16 / 93$ & 900-Mile Salmon Patrol Drawing To A Close \\
\hline $9 / 14 / 93$ & Support For Salmon High, Violations Low Among Idaho Anglers \\
\hline $10 / 5 / 93$ & Steelheaders: Know Your Catch \\
\hline $4 / 1 / 94$ & Game Wardens To Talk On Salmon Poaching \\
\hline $4 / 21 / 94$ & Anglers Take Note: Trout Or Protected Salmon? \\
\hline $4 / 22 / 94$ & Make Sure That Fish Is Legal \\
\hline $5 / 4 / 94$ & Poached Salmon No Longer On Menu \\
\hline $5 / 13 / 94$ & OSP Issued Two Citations To James Boyd \\
\hline $5 / 16 / 94$ & Enforcement Blitz Contributes To Higher Adult Salmon Survival \\
\hline $5 / 23 / 94$ & Fisheries Pilot Killed In Private Plane Crash \\
\hline $6 / 2 / 94$ & Irrigation Pump Screens Reveal . \\
\hline $6 / 16 / 94$ & $\begin{array}{l}\text { Fisheries Service To Meet With Ranchers About Salmon } \\
\text { Protection }\end{array}$ \\
\hline $7 / 5 / 94$ & Sentencing due For Poaching Violations \\
\hline $7 / 6 / 94$ & $\begin{array}{l}\text { Sockeye Salmon Netpen Project Gets Underway In Redfish Lake } \\
\text { (Sharon Blair) }\end{array}$ \\
\hline $7 / 28 / 94$ & Quick Repair Of Fish Screens Saves Salmon \\
\hline $8 / 10 / 94$ & $\begin{array}{l}\text { Endangered Species Act, Salmon Law Enforcement Focus Of } \\
\text { Upcoming Public Meetings }\end{array}$ \\
\hline $9 / 8 / 94$ & Salmon Spawning Prompts River Access Restrictions \\
\hline $9 / 14 / 94$ & OSP Officers Begin To Emphasize Environmental Crime \\
\hline 9/23/94 & Anglers Note: Protected Salmon Present In Steelhead Waters \\
\hline $9 / 30 / 94$ & WDFW To Emphasize Environmental Enforcement \\
\hline $10 / 6 / 94$ & CBSET Summer Emphasis Patrols Termed A Quiet Success \\
\hline
\end{tabular}


APPENDIX 4. THE COLUMBIA RIVER INDIVIDUAL ACTIVITY REPORT DEVELOPED BY OREgON STATE POLICE. 

YEAR

OFFICER

AGENCY

- REPORT ONLY ONE AREA PER LINE. IF OTHER AREAS ARE WORKED DURING THE SAME DAY, USE SEPARATE LINE FOR EACH.

- DO NOT REPORT ARRESTS OR SEIZURES WHICH ANOTHER OFFICER/AGENT IS REPORTING.

- ALl AREA LETTER DESIGNATIONS ARE ON THE BACK PAGE OF THIS REPORT.

For CBLEC reporting purposes, the total area hours reported on a daily basis must equal the total hours reported as commercial, sport or ceremonial. In addition, they can be charged to the other categories as well. For example: an 8-hour shift within the zone which involved an interagency commercial effort would be reported as 8 hours patrol commercial as well as 8 hours interagency.

TOTALS

\begin{tabular}{|c|c|}
\hline & DAY OF MONTH \\
\hline & AREA \\
\hline & AREA HOURS \\
\hline C & $\begin{array}{l}\text { HOURS PATROL } \\
\text { COMMERCIAL }\end{array}$ \\
\hline $\mathbf{B}$ & $\begin{array}{l}\text { HOURS PATROL } \\
\text { SPORT }\end{array}$ \\
\hline $\mathbf{L}$ & $\begin{array}{l}\text { HOURS PATROL } \\
\text { CEREMONIAL }\end{array}$ \\
\hline $\mathbf{E}$ & $\begin{array}{l}\text { HOURS PATROL } \\
\text { AIRCRAFT }\end{array}$ \\
\hline C & $\begin{array}{l}\text { HOURS PATROL } \\
\text { INTERAOENCY }\end{array}$ \\
\hline & $\begin{array}{l}\text { HOURS REPORT } \\
\text { WRITINO }\end{array}$ \\
\hline $\mathbf{D}$ & INVESTIOATION \\
\hline A & ENVIRONMENTAL \\
\hline $\mathbf{T}$ & SALMON SEIZED \\
\hline $\mathbf{A}$ & STURGEON SEIZED \\
\hline & $\begin{array}{l}\text { \# ARRESTS } \\
\text { COMMERCIAL }\end{array}$ \\
\hline & $\begin{array}{l}\text { \# ARRESTS } \\
\text { SPORT }\end{array}$ \\
\hline & NETS/GEAR SEIZED \\
\hline & $\begin{array}{l}\text { ENFORCEMENT } \\
\text { CONTACTS }\end{array}$ \\
\hline $\mathbf{0}$ & $\begin{array}{l}\text { HOURS PATROL } \\
\text { BOAT }\end{array}$ \\
\hline S & $\begin{array}{l}\text { \# WARNINOS } \\
\text { COMMERCIAL }\end{array}$ \\
\hline $\mathbf{P}$ & \#WARNINGS SPORT \\
\hline & OVERTIME HOURS \\
\hline D & $\begin{array}{l}\text { COMPLAINTS } \\
\text { COMMERCIAL }\end{array}$ \\
\hline$A$ & $\begin{array}{l}\text { COMPLANNTS } \\
\text { SPORT }\end{array}$ \\
\hline$T$ & $\begin{array}{l}\text { COMPLAINTS } \\
\text { ENVIRONMENTAL }\end{array}$ \\
\hline A & VEHICLE MILEAGE \\
\hline
\end{tabular}




